\title{
ARISTOCRACIA ALADA, ADALides DEL REY DEL CiElo. ÁNGEles Militares EN LA PINTURA BARROCA AMERICANA*
}

\author{
Sergi Doménech García \\ Universitat de València
}

RESUMEN: El presente trabajo aborda el estudio de las imágenes de los ángeles militares en los virreinatos americanos y su interpretación a partir de la función cultural de las imágenes. Para ello se analizan las distintas tipologías visuales del arcángel san Miguel en el virreinato de Nueva España y su uso regiopolítico, la definición beligerante del resto de ángeles en la tradición teológica y la imagen de los conocidos como arcángeles arcabuceros. Identifica la tradición bélica del lenguaje posterior al concilio de Trento y, en el caso de los arcángeles arcabuceros, defiende su vinculación con la fiesta barroca.

Palabras clave: san Miguel, Eucaristía, arcángeles arcabuceros, monarquía hispánica, Inmaculada Concepción.

ABSTRACT: The present work focuses on the study of images of military angels in American Colonial Art and their interpretation from the perspective of the cultural function of the image. Therefore, we analyze visual typologies of Saint Michael in the Viceroyalty of the New Spain and their political usage in the region, the belligerent definition of the rest of the angels in the theological tradition, and the image of those known as Arquebus Archangels. The article identifies the military tradition of the language after the Council of Trent and, in the case of the Arquebus Arcangels, defends their vinculation with the baroque festival.

Keywords: Saint Michael, Eucharist, Arquebus Archangels, Hispanic Monarchy, Immmaculate Conception.

\footnotetext{
* El presente trabajo forma parte del proyecto I+D, «Los tipos iconográfico» HAR2015-65176-P, del
} Ministerio de Economía y Competitividad. 
$\mathrm{E}_{\mathrm{se}}^{\mathrm{n}}$ la tradición teológica, y en consecuencia también en su traslado visual, se consolidó la visión del cielo a modo de una monarquía celeste donde Dios es quien, asentado en el solio regio, preside los designios del mundo. La consecuencia en la angelología cristiana, tal y como quedó asentado tras la Jerarquía celeste del Pseudo Dionisio, fue llegar a una visión donde los ángeles se entienden como sus principales asistentes y se estructuran según sus desempeños y en relación con la divinidad, en una visión neoplatónica de la monarquía celeste. Esta consideración de siervos directos de la Trinidad y de la Virgen tuvo un despliegue amplio en la visualidad artística de los virreinatos americanos donde se dieron numerosas tipologías iconográficas de ángeles representados en acciones y formas que los identifican como jefes de las milicias angélicas, a modo de altos mandatarios bélicos. Su aparición tiene lugar en series angélicas, en cultos aislados, pero también en las fiestas barrocas y por medio de la pervivencia de sus hazañas bélicas en el imaginario colectivo. Este amplio repertorio incluye desde los habituales tipos iconográficos angélicos -en especial los referentes a los tres canónicos-, hasta la que fue, sin duda, la tipología más peculiar, la de los arcángeles arcabuceros, alabarderos y portaestandartes. Tipos iconográficos de carácter conceptual, a pesar de que la mayoría de imágenes estén fundamentadas en episodios narrativos.

El estudio de la tradición visual de ángeles militares en el arte virreinal americano da como resultado la existencia de diversas tipologías que atienden a un amplio muestrario que abarca las distintas artes, como la pintura o la escultura. En cuanto a la naturaleza de su representación se encuentran, por un lado, las imágenes narrativas, que se corresponden con la traducción visual de escenas proveniente de las diversas fuentes literarias, ya sean bíblicas, hagiográficas o leyendas. El análisis de estas imágenes serviría para establecer el modo en el que se ha llevado a cabo la continuidad y variación de tipologías que, por lo general, se originaron en el arte medieval cristiano. Pero, por otro lado, se encuentra un conjunto de manifestaciones de carácter conceptual que pudiendo encontrar el origen igualmente en modelos del Viejo Continente, desplegaron una evidente originalidad que ha llamado la atención a los estudiosos del arte virreinal. El análisis de estas representaciones permite abordar asuntos relativos a la imagen del poder en el mundo hispánico, donde las figuras de estos seres angélicos se convierten en reflejo del orden monárquico virreinal y en expresión de la acción apologética llevada a cabo por el cristianismo. El presente trabajo se centra en el estudio de este segundo grupo, estudiando la formación de estas tipologías así como el ámbito conceptual e imaginario que las sustenta, no sin desoír los principios que se definen en la tradición cultural convencionalizada anterior a su aparición.

La definición de los seres angélicos, en virtud de su naturaleza, situación jerárquica y función dentro del orden del mundo y la creación, tuvo lugar en un dilatado proceso vivido por el cristianismo, lo que conllevó un ejercicio de depuración de toda la tradición heredada del mundo hebreo, del que se había aprehendido su figura. La obra más influyente, cuya sistematización se 
convirtió en la base para la angelología cristiana, fue la Jerarquía celeste del Pseudo Dionisio. Esta obra, -cuya autoría inicial fue adjudicada erróneamente al obispo ateniense Dionisio Aeropagita- influyó de forma decisiva sobre la mentalidad teológica, y por ende estética, de la Edad Media. La lectura de la corte angélica estaba formada por un total de nueve coros angélicos agrupados en tres jerarquías. Cada uno de estos órdenes estaba dedicado a una ocupación concreta, en virtud de su posición y proximidad a Dios. La jerarquía de los distintos espíritus venía definida según la proximidad a la divinidad, en una lectura luminiscente. De la misma forma se establecían las funciones y prerrogativas de cada uno de los coros en función de esta situación. Santo Tomás también se ocupó de este asunto -siguiendo al Pseudo Dionisio- en el «Tratado de los ángeles», inserto en su Suma Teológica, y a él recurren los posteriores autores angélicos, los cuales siguen la concepción de la jerarquía celeste como una monarquía, regida por Dios. Las jerarquías quedaban divididas, según santo Tomás, en atención a las funciones que realizan estos seres. En concreto, sería trabajo de los cuatro órdenes primarios, a los que santo Tomás llama ángeles asistentes de Dios, -serafines, querubines, tronos y dominaciones, que pertenecen a la primera jerarquía y al primer orden de la segunda- el estar ocupados solamente en alabar y glorificar a Dios. Estos cuatro no se distraen en atender funciones exteriores ni disposiciones del gobierno monárquico. Esto último le correspondería a los otros cinco órdenes. A estos los llama ministrantes, porque son ministros y oficiantes de Dios, por cuya mano corren los despachos y ejecuciones de su providencia, en orden al gobierno del Universo.

La imagen de los ángeles militares -en sus diversas tipologías- responde a esta visión del cielo como un reino jerárquico, una idea general que se encuentra entre los conceptos básicos y fundacionales de la Iglesia desde su oficialidad. Con la aparición de las primeras comunidades cristianas, y debido a las sucesivas persecuciones vividas por sus miembros primitivos, se fue afianzando la idea del triunfo del cristianismo frente a sus opositores.

La idea de la Iglesia acechada por el mal -encarnado por su principal representante, el demonio, pero también por sus seguidores terrenales como los enemigos políticos, los infieles y, muy especialmente, los herejes- forma parte del discurso del cristianismo desde los orígenes y terminó por impregnar su lenguaje y, con ello, también la visualidad artística. En los años previos a la paz de la Iglesia y su oficialidad en el Imperio romano se asentaron las bases de la existencia de esa situación de eterno conflicto. Quizás el ejemplo más notable es el papel que ocuparon los primeros mártires del cristianismo, víctimas de las persecuciones llevadas a cabo por el Imperio romano. Alrededor de estas figuras se fue generando la práctica religiosa. En este tiempo, la Iglesia necesitó del aliento que la esperanza en la salvación postrera, con el advenimiento del Reino de Dios prometido por Cristo. En relación con este aspecto se configura la imagen beligerante y triunfal de los seres angélicos como huestes encargadas de vencer a las tropas demoniacas. Esa fue la lectura exegética que, tal y 
como se recoge en los textos de los primeros padres- tuvo la revelación al evangelista san Juan en Patmos. De hecho, dos episodios del Apocalipsis fueron determinantes en la configuración de este ideario. Por un lado, el triunfo de san Miguel contra la bestia de siete cabezas (Ap 12, 7-9) y, por otro, el encadenamiento del demonio por mil años (Ap 20,1-2). ${ }^{1}$ La transposición visual de estos conceptos no se detiene únicamente en la ilustración de estas escenas narrativas, sino que los ángeles guerreros aparecen enzarzados en batallas contra todo tipo de seres demoniacos en multitud de escenas donde se convierten en metáfora de la lucha que la Iglesia lleva a cabo en la salvaguarda de la fe y las verdades teologales. Se trata de imágenes que, en su mayoría, están definidas por su carácter apologético y que remiten, por tanto, a la pervivencia de la idea del cristianismo atacado y la Iglesia beligerante.

La idea del Reino de Dios se introduce por primera vez en las parábolas evangélicas por medio de la figura de Cristo cuando explica la promesa salvífica del Padre. De ahí las futuras comparaciones que se sustentan en una distribución jerárquica que incluye la presencia de un solio regio donde la divinidad se presenta ante sus vasallos y en compañía de una corte formada por la Virgen, los ángeles y los santos. Sobre esta construcción se asientan las posteriores reflexiones angelológicas que se detienen en definir el lugar que ocupan y el desempeño llevado a cabo por los ángeles. Otra fuente relevante es el salmo 109 -siguiendo la numeración de la Vulgata- que sirvió para representar visualmente a Cristo sentado a la derecha del Padre, origen de la iconografía de la Trinidad. ${ }^{2}$ Este aspecto fue significante a la hora de la formación del imaginario medieval, como se deduce del estudio de tipologías cristológicas como el Pantocrator, mariológicas como la coronación de la Virgen o angélicas, donde destaca el caso del arcángel san Miguel.

La terminología bélica también fue empleada de forma habitual por los representantes de la Iglesia para significar el carácter militante de su labor de salvaguarda de la fe. Así como existía un reino en el cielo donde Dios disponía de su propio ejército, en la tierra los padres de la Iglesia, teólogos y representantes del poder eclesiástico dispusieron un número considerable de semejanzas, paralelismos, metáforas y símbolos asentados en la misma visión.

Existió un reflejo de esta interpretación también en las cruzadas y procesos de conquista -tanto peninsular como americano- donde los ejércitos

1. La apocalíptica bestia de siete cabezas que el arcángel Miguel vence fue interpretada inicialmente como símbolo de la Roma pagana, perseguidora de cristianos, recurso que fue adaptado en posteriores ocasiones para significar el triunfo sobre las herejías, el protestantismo y los pecados capitales. Véase SERGI DOMÉNECH GARCíA: «Iconografía de la Mujer del Apocalipsis como imagen de la Iglesia», en RAFAEL García Mahíques, Vicent Zuriaga Senent (eds.): Imagen y cultura. La interpretación de las imágenes como Historia cultural, Biblioteca Valenciana, Valencia, tomo I, 2008, pp. 563-580.

2. Véase Elvira Mocholí Martínez: «El salmo 109 como origen de la iconografía de la Trinidad», en Rafael Zafra, José Javier Azanza (eds.): Emblemática trascendente. Hermenéutica de la imagen, iconología del texto, Anejos de Imago, Universidad de Navarra, Pamplona, n. ${ }^{\circ} 1,2011$, pp. 495-506; Elvira Mocholí Martínez: «La Trinidad del salterio», en Rafael García Mahíques (dir.): Los tipos iconográficos de la tradición cristiana (vol. 1). La visualidad del Logos, Ediciones Encuentro, Madrid, pp. 433 y sig. 
actuaban en nombre de Dios y el catolicismo. Este discurso estuvo avivado en dos momentos especiales. Por un lado, por parte de los primeros religiosos dedicados al proceso de evangelización de los territorios americanos que actuaron como milicias misionales contra la idolatría que había que extirpar en el continente. Por otro se encuentran las guerras contra el protestantismo, movimiento religioso cuya aparición había atacado el corazón mismo del catolicismo y amenazó con desquebrajarlo. La actitud de los reformadores fue grave para la Iglesia, en el sentido que atacaron aspectos esenciales del cristianismo romano como son el dogma eucarístico, la autoridad papal, el culto a los santos y a la Virgen o la veneración de las reliquias y sagradas imágenes. No hay que olvidar, como señalaremos más adelante, que el modo en el que se tradujo visualmente esa lucha y defensa por la fe fue por medio de la articulación de una visión militarizada del discurso apologético.

Pero, sin duda, el ejemplo más significativo fue el de la Societas Jesu o Compañía de Jesús. Su fundador, Ignacio de Loyola, había participado en acciones bélicas en las tropas de Carlos V. Oficialmente la nueva orden estuvo aprobada por el papa Paulo III en 1540, por medio de la bula -de nombre muy significativo-Regiminis militantes Eclesias. En esta quedaba aprobada la conocida fórmula del Instituto, que comprometía a los jesuitas a «militar para Dios bajo la bandera de la cruz». Ignacio conseguirá de Paulo III la ampliación de dicha fórmula por medio de la aprobación de una nueva bula, en 1550, quedando de la siguiente manera: «Militar para Dios bajo la bandera de la cruz y servir solo al Señor y a la Iglesia, su Esposa, bajo el Romano Pontífice, Vicario de Cristo en la tierra». ${ }^{3}$ El grupo recudido de hombres que encabezaba Loyola ya era conocido, en 1538, con el nombre de Compañía de Jesús. Su desempeño fue relevante en la lucha contra el protestantismo, así como en la defensa de los principios que, unas décadas después, habían de quedar establecidos por la iglesia por medio del concilio de Trento. Resulta evidente la influencia de los textos caballerescos y militares en la conformación de la Compañía que se declara en la elección del mote militar "Compañía» y del resto de disposiciones establecidas en sus Constituciones. La orden estaba formada por un «ejército» de hombres que habían de dedicar su vida y desempeño a defender a Dios o, como repetía en sus escritos san Ignacio, Ad maiorem Dei gloriam, expresión que se convertiría en lema de los jesuitas. Encabezaba la estructura jerárquica de la orden un Prepósito General, seguido por una Congregación General y otros mandos como los generales provinciales.

En resumen, desde los primeros años del cristianismo, y pasando por el concilio de Trento, se generó la imagen de la Iglesia militante encargada de desempeñar una labor apologética. Estos aspectos convergen también en las diferentes tipologías angélicas, ampliando las posibilidades de su adecuación a un discurso del poder en territorio americano. En cierta manera la repre-

3. José García Castro (dir.): Diccionario de espiritualidad ignaciana, vol. 2, Ediciones Mensajero, Bilbao, 2007, p. 1244. 
sentación, por parte de los artistas del periodo virreinal americano, de los ángeles tomando la apariencia de altos mandos militares, guarda una deuda notable con la tradición, originada desde época medieval, de representación de ángeles combatientes. Pero lo cierto es que su configuración responde a la tradicional retórica adoptada tras el concilio de Trento y a la forma concreta en la que se introdujo el lenguaje bélico en la práctica doctrinal, la literatura teológico-apologética y la visualidad artística. Desde los textos de la oficialidad eclesiástica, los tratados teológicos, los sermones y los escritos piadosos se puede apreciar esta visión de la existencia de un cuerpo celeste en armas, formado por ángeles dispuestos a salvaguardar los principales dogmas y principios católicos.

El ejemplo más emblemático lo constituye la imagen del arcángel san Miguel, identificado como capitán de las milicias celestes. La fuente principal que da sustento a esta idea se encuentra en el Apocalipsis, en el mencionado capítulo 12. La liturgia griega lo definía con el apelativo de archiestratega, expresión que lo identifica "como comandante supremo de las huestes aladas», recogiendo literalmente las palabras del Segundo Libro de Enoc (2 Enoc 22,6, 33 y 11). ${ }^{4}$ Las implicaciones culturales de la imagen de san Miguel en los virreinatos americanos se aprecia especialmente -aunque no de forma exclusiva- en el Virreinato de Nueva España, en atención al modo en el que se fraguó la particular participación en la defensa del dogma eucarístico y del misterio inmaculista, y a la adaptación al culto local de la Virgen de Guadalupe. El origen de estas figuraciones y su interpretación se encuentran en la vinculación del culto a este arcángel con las monarquías. El jesuita Eusebio de Nieremberg deja escrito en su tratado sobre san Miguel el uso que los monarcas europeos hicieron de este ángel para combatir la idolatría y su especial relación con la historia hispánica recordando cómo los visigodos abdicaron del arrianismo en el día dedicado a dicho ángel. El vínculo se acentúa con la dinastía de los Austrias donde Nieremberg apunta que Rodolfo I fue electo emperador en ese mismo día. Además, para este jesuita había sido destinado como especial «ángel de la guarda de la Santísima Virgen desde el instante mismo de su concepción». ${ }^{5}$ En Nueva España, el culto a san Miguel ocupó un lugar destacado. Santuarios como el de San Miguel de las Cuevas en Chalma lo testifican y, muy especialmente, el culto a san Miguel del Milagro, cuya historia fue descrita por Francisco de Florencia, ${ }^{6}$ con lo que se vivió un aumentó considerable de su devoción a partir del último tercio del siglo Xvir. ${ }^{7}$

4. Enric Olivares Torres: «San Miguel archiestratega y capitán de las milicias celestes», en RAFAEL García MahíQues (dir.): Los tipos iconográficos de la visualidad cristiana, vol. II, Ediciones Encuentro, Madrid, en prensa.

5. Rosario InÉs Granados SAlinas: «Una travesía con olor a yauhtli: el descenso de la imagen al Tepeyac», en El Divino pintor. La creación de María de Guadalupe en el taller celestial [cat. exp.], Museo de la Basílica de Guadalupe / Museo de Historia de Monterrey, México, 2001, p. 214.

6. Francisco de Florencia: Narración de la maravillosa aparición que hizo el arcángel s. Miguel a Diego Lázaro de S. Francisco, Thomás López de Haro, Sevilla, 1692.

7. GRANADOS, «Una travesía con olor a yauhtli», pp. 217-218. 
Una temática singular de la relación entre el culto angélico y el poder monárquico se encuentra en las representaciones de san Miguel en defensa de la Inmaculada Concepción. En base a una actividad diplomática y de posicionamiento dentro del catolicismo, la monarquía hispánica actuó como principal garante de la defensa de la doctrina concepcionista que no gozaba de reconocimiento dogmático - logrado hasta 1854- y sobre la cual perduró durante siglos una notable controversia. Esta actitud dibujaba un perfil propio para la monarquía hispánica. El trabajo de la institución regia se centró en la actividad diplomática, haciendo uso de su influencia con el papado para conseguir el reconocimiento dogmático de la Inmaculada Concepción, convirtiendo dicho empeño en un aspecto fundamental de sus reinados. Este ímpetu tenía el propósito de tomar a la Inmaculada como un instrumento de cohesión social y política del vasto territorio hispánico, el cual incluía varios reinos peninsulares y los virreinatos americanos. ${ }^{8}$ En cierta forma, las órdenes religiosas, especialmente los franciscanos junto con los cabildos catedralicios, hicieron el trabajo directo de esta actividad de promoción. En atención a este propósito se hicieron habituales -además de las acciones diplomáticas- la promoción de celebraciones, el patrocinio artístico y literario, así como la organización de un programa visual apologético donde la monarquía junto con el resto de poderes civiles y eclesiásticos, o sus emblemas definitorios, aparecían a los pies de la Inmaculada.

En esta línea se inscriben diversos tipos iconográficos de san Miguel, como el que lo muestra portando un estandarte con la representación de la Inmaculada. Este tipo iconográfico se configura como una variante de la imagen de san Miguel archiestratega. El arcángel es representado con atavíos militares «a la romana», esto es, portando loriga o coraza y la clámide griega, a modo de un alto mando. En el seno de la defensa de la doctrina de que María había sido librada del pecado original desde el primer instante de su concepción se generaron estos blasones con la imagen de la Inmaculada portados por santos y personalidades de la época. El origen simbólico del estandarte se encuentra en los blasones militares que encabezaban la tropa, identificándolos a todos en un mismo grupo, marcando el motivo por el cual luchaban. Juntos con otros símbolos -tales como los escudos reales-, los lábaros y pendones fueron las enseñas capaces de mover e identificar a un ejército y a su pueblo. El estandarte también es en sí mismo un objeto religioso, pues encabezaba a las cofradías y feligreses en diversos actos litúrgicos. Estas procesiones tenían lugar en momentos señalados del calendario festivo. Los monarcas españoles también se sirvieron de ser representados portando un blasón con la imagen de la Inmaculada, como es el caso de Felipe IV en un grabado de Marcos Orozco que ilustra la portada del libro Philipo IIII Hispaniarum Regi Catholico del jesuita

8. IvÁN MARtínez: «Estandarte de la monarquía española. El uso político de la Inmaculada Concepción», en Un privilegio sagrado: La Concepción de María Inmaculada. La celebración del dogma en México, Museo de la Basílica de Guadalupe, México, 2005, p. 125. 
Juan Antonio Velázquez. ${ }^{9}$ La creación de esta imagen de san Miguel portando el estandarte inmaculista revela el carácter hispánico del tipo iconográfico y su disposición política.

No escapa a nuestra atención que tras la formación de esta tipología se encuentra nuevamente el Apocalipsis, donde la mujer - mulier amicta soleque el arcángel defiende de la bestia de siete cabezas, había sido identificada con la Inmaculada. ${ }^{10}$ Es de esta forma como se asocia principalmente la figura de san Miguel con la defensa del misterio concepcionista. Pero el origen del propio tipo se produce por su asimilación como patrono del imperio y de la especial custodia del asunto de la Inmaculada que hicieron los monarcas españoles. La creación del tipo iconográfico puede haber sido incitada por el grabado de Augustin Bouttats, de 1682 [Fig. 1]. Este ilustraba el libro de Antonio de Santa María dedicado a Felipe IV y titulado España triunfante y la iglesia laureada por todo englobo del mundo por el patrocinio de María Santísima. En él se muestra una personificación de España con los atributos bélicos de la diosa Atenea, con coraza, yelmo y estandarte. La novedad en esta imagen es la inclusión en el interior del estandarte de una imagen de la Inmaculada con las iniciales «S.P.Q.HISP.» (El Senado y el Pueblo Hispánico). ${ }^{11}$ La obra está dedicada al ya entonces fallecido Felipe IV y se inserta dentro de la producción apologética a favor del reconocimiento dogmático del misterio. La similitud de esta imagen con san Miguel debió facilitar la aparición del tipo iconográfico. Una pintura cuzqueña realiza un traslado directo de este grabado sustituyendo la alegoría de España por el arcángel como príncipe de las milicias celestiales [Fig. 2]. Formalmente es idéntica pero la inscripción de la lápida ${ }^{12}$ se ha modificado, indicando que se trata de un reconocimiento de la labor de patrocinio de san Miguel sobre el territorio hispánico.

Ciertamente no se trata de un tipo iconográfico ampliamente extendido y su existencia se reduce al ámbito hispánico. Cristóbal de Villalpando realizó un lienzo con este asunto, hoy en una colección particular. ${ }^{13}$ San Miguel aparece

9. Felipe IV aparece desprendido de sus armas terrenales y enarbolando dicho estandarte inmaculista. En su otra mano porta un globo terráqueo mientras está siendo coronado por la Fama y la Victoria. IváN MARTínez, «Estandarte de la monarquía española», pp. 123-154; JAIME CUADriello: «Virgo potens' La Inmaculada Concepción o los imaginarios del mundo hispánico», en JuANA GutiérRez HaCes (coord.): Pintura de los reinos. Identidades compartidas. Territorios del mundo hispánico siglo XVI-XVIII, vol. 4, Fomento Cultural Banamex, México, 2008, pp. 1169-1263.

10. El tipo definitivo de la Inmaculada Concepción de María se había construido, en gran parte, gracias a su identificación con la Mujer del Apocalipsis. Sergi Doménech García: «La recepción de la tradición hispánica de la Inmaculada Concepción en Nueva España. El tipo iconográfico de la Tota Pulchra», Espacio, tiempo y forma. Serie VII, Historia del arte, 3. Nueva Época, (2015), pp. 725-309; SERGi DomÉnECH GARCíA: La imagen de la Mujer del Apocalipsis en Nueva España y sus implicaciones culturales, tesis de doctorado, Universitat de València, 2013.

11. Suzzanne Stratton: La Inmaculada Concepción en el arte español, trad. de José L. Checa, Fundación Universitaria Española, Madrid, 1989, p. 112.

12. «España triunfante y la Iglesia laureada en todo el globo del mundo por el patrocinio de S. ${ }^{\mathrm{n}}$ Miguel en España».

13. Este lienzo estuvo expuesto en la muestra titulada Pintura de los Reinos. Identidades compartidas en el mundo hispánico, que se celebró en el Museo de Prado y el Palacio Real de Madrid, del 26 de octubre de 2010 al 31 de enero de 2011. 


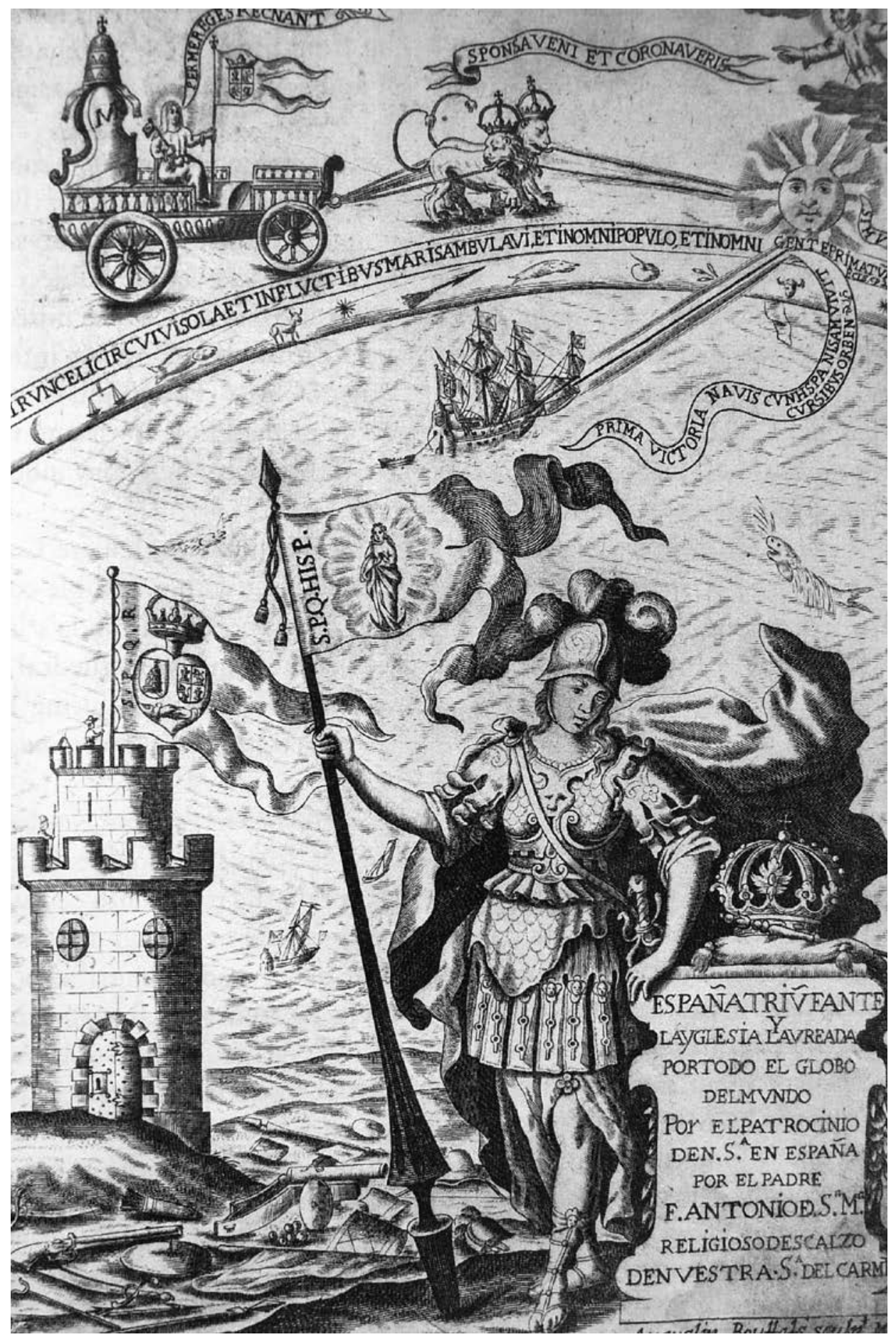

Fig. 1. Augustin Bouttats, Alegoría de España Triunfante con estandarte inmaculista, 1682, portada de España triunfante y la iglesia laureada por todo englobo del mundo por el patrocinio de María Santísima, Antonio de Santa María, Hispanic Society of New York 


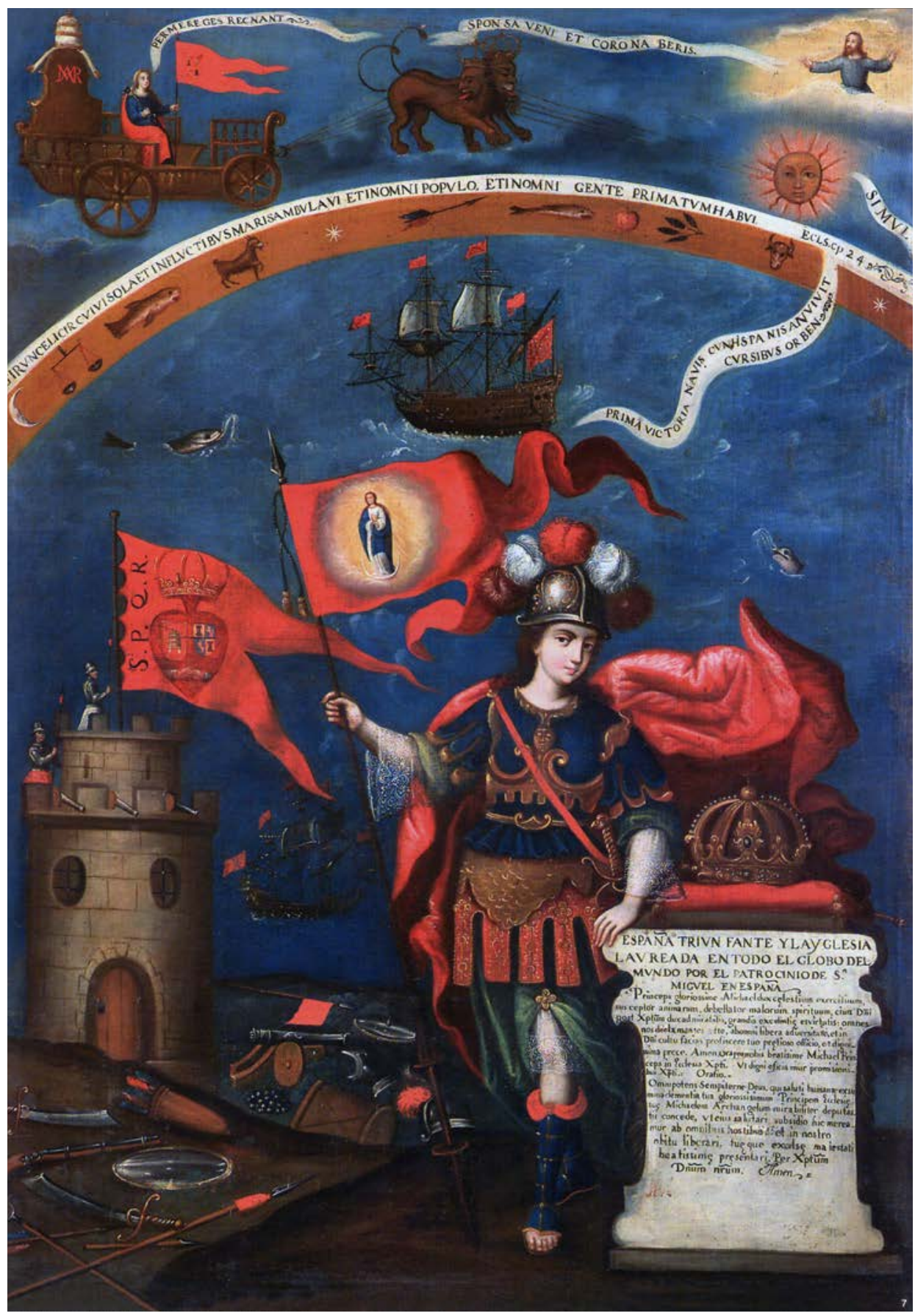

Fig. 2. Anónimo CuzQueÑo, San Miguel como patrono de España, s. XVIII, Colección Marí Solari, Lima 
de pie vestido con armadura y cargando con el estandarte inmaculista. Este ejemplo constituye el modo habitual de representación del tipo iconográfico. En las representaciones de san Miguel entre los Siete Príncipes era común mostrarlo portando el habitual lábaro con el triunfal guión blanco con la cruz. En algunas ocasiones este último atributo podía ser sustituido por un estandarte inmaculista. Los ejemplos de esta variante del tipo se concentran en la ciudad de Oaxaca, en México, y pertenecen a talleres del siglo XVIII, como en el templo de Santo Domingo, en el templo de los Siete Príncipes o en la iglesia de San Pablo en Mitla, en la misma región.

A partir de la segunda mitad del siglo xviI, la imagen de la Virgen de Guadalupe se convirtió en un equivalente mexicano de la Inmaculada Concepción, aunque el impacto de esa interpretación en la visualidad artística no fue significativo hasta el segundo tercio del siglo XVIII. El discurso concepcionista se vio enriquecido en el antiguo Virreinato de Nueva España con el auge del culto a la Virgen de Guadalupe que, en su tipología iconográfica, estaba del todo cercana a la imagen de la Inmaculada y no faltaron comparaciones. Todo ello, sumado al papel de san Miguel como patrono del Virreinato de Nueva España, dan como resultado esta variante del tipo, ${ }^{14}$ que presenta al arcángel portando un estandarte con la imagen de la Guadalupana. Este hecho se encuentra apoyado en la exégesis iniciada por Miguel Sánchez quien, en su libro Imagen de la Virgen María Madre de Dios de Guadalupe (1648), comparó el lienzo acheropita del Tepeyac con la Mujer del Apocalipsis. ${ }^{15}$ A este tipo responde el san Miguel del Altar de los Siete Príncipes, de Juan Baltasar Gómez, una obra del siglo XviII que se encuentra en el templo de la Santa Escuela de Cristo, en San Miguel Allende [Fig. 3].

En la línea de esta imagen triunfal de san Miguel sobre la idolatría y el pecado se fraguó una defensa hispánica de la fe católica -con especial mirada hacia el enemigo protestante- que tuvo como sus principales sustentos el dogma eucarístico y el misterio concepcionista. El primero de ellos había estado negado por el protestantismo que no creyó en la eucaristía como auténtica transubstanciación de las especies en el cuerpo y la sangre del Cristo. También es cierto que existió oposición por parte de estos hacia la Inmaculada Concepción, pero en este caso la defensa se hace ante los ataques maculistas internos. El misterio concepcionista se eleva al mismo nivel que el dogma eucarístico bajo el manto de protección y el auspicio de la monarquía hispánica. Fueron diversos los modelos que sirvieron para representar esta unión y que toman como núcleo esta imagen de san Miguel luchando contra la bestia. El origen de la formación de este tipo eucarístico del triunfo de san Miguel

14. JAIME CUADRIELlo: «El obrador trinitario o María de Guadalupe creada en idea, imagen y materia», en El Divino pintor. La creación de María de Guadalupe en el taller celestial [cat. exp.], Museo de la Basílica de Guadalupe / Museo de Historia de Monterrey, México, 2001, pp. 61-205; DoméneCH, La imagen de la Mujer del Apocalipsis.

15. Jaime CuAdriello: «Visiones en Patmos-Tenochtitlan: La mujer-águila», en Nelly Sigaut (ed.): La iglesia católica en México, Colegio de Michoacán, México, 1997, pp. 265-292. 


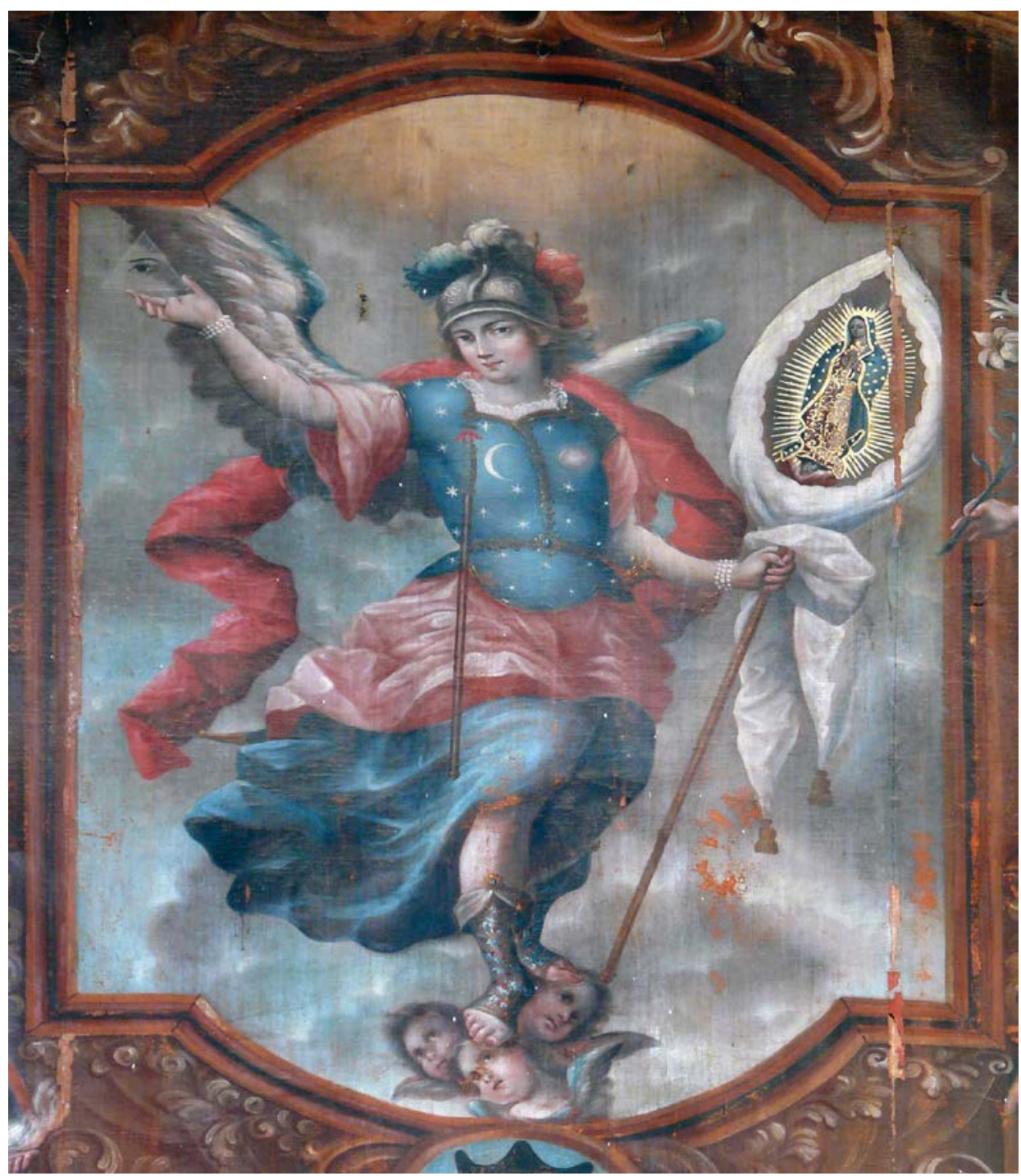

Fig. 3. Juan Baltasar Gómez, San Miguel con estandarte inmaculista, s. XviII, retablo de los Siete Príncipes, Iglesia de la Santa Escuela de Cristo, San Miguel Allende, Estado de Guanajuato (México)

sobre la bestia se encuentra en el propio capítulo 12 del Apocalipsis donde la victoria del capitán angélico y sus ángeles dice haber sido alcanzada «por medio de la sangre del Cordero y de la palabra del testimonio de ellos» (Ap 12, 11). La generación de estas obras novohispanas debió estar propiciada por la circulación de algún grabado devocional que, a manera de modelo original de difusión, fue adaptado en Nueva España. Este grabado desconocido respondía a la promoción hispánica característica de la época dorada del inmaculismo 
español del siglo XVII, con indulgencias incluidas, ${ }^{16}$ aunque pudo haberse fraguado en los talleres del virreinato novohispano. La prueba más evidente de su existencia es que conservamos diversas obras que parecen seguirlo de cerca, como una pequeña lámina del Museo Amparo de Puebla.

Los tipos presentes en la tradición pictórica novohispana conectan con la política de los Austrias en defensa de la Inmaculada y su especial relación con el Santísimo Sacramento pero se realizan de nuevo durante el siglo XviII, en medio de un contexto de recuperación visual de aquel ímpetu. ${ }^{17}$ Por lo general presentan a san Miguel espada en mano portando en la otra una custodia y unas cadenas con las que aprisiona a la bestia de siete cabezas. La inclusión en el fondo de la Virgen de Guadalupe nos recuerda su papel como Inmaculada novohispana. Quizás la muestra más potente de este juego de intenciones sea un lienzo atribuido a Miguel Cabrera que pertenece al Museo de la Basílica de Guadalupe de México [Fig. 4]. El arcángel aparece ataviado con su habitual vestimenta. Cada una de las cabezas del dragón está identificada con uno de los siete pecados capitales. En lugar de una custodia, carga en su mano un cáliz con una hostia. La cadena que aparece en este tipo iconográfico singular remite al vigésimo capítulo del Apocalipsis (Ap 20,1-2) en el que se indica que un ángel ataría al demonio por mil años. Aunque el texto del evangelista san Juan no identifica a este ser angélico, la tradición ha querido ver a san Miguel como el ejecutor de tal acción. Un ejemplo de esta identificación se encuentra en Eusebio de Nieremberg quien llega a decir que «... tanto poder tuvo san Miguel contra el mayor de los Demonios, que le ató como a un perro sin resistencia alguna». ${ }^{18}$ Este jesuita expuso estas palabras en su obra dedicada a san Miguel Devoción y patrocinio de san Miguel, príncipe de los Ángeles, Antiguo tutelar de los godos y protector de España, aparecida en 1643, donde reconoce su papel de defensor sobre la monarquía hispánica.

Conviene señalar otro aspecto de esta composición como es la aparición de la Virgen como la mulier amicta sole (Ap 12), con el par de alas llevando a su hijo hacía Dios Padre. ${ }^{19}$ Su inclusión concuerda con la lógica narrativa y con la tradición visual. Si lo comparamos con las habituales representaciones de la Inmaculada apocalíptica vemos que aparecen los mismos protagonistas y atributos. Únicamente se ha modificado - por medio de una conceptualización que aumenta el carácter simbólico de esta escena narrativa- al amplificar su

16. Una de las obras pictóricas devocionales conservadas en el Museo Amparo de puebla presenta la siguiente inscripción: «S.r S. $^{\mathrm{n}}$ Miguel Arcanjel Primer coronel de la Escuadra de M. Srna defien / denos. Ssmo Papa Gregorio XV concedio 100 años de indulgencia a todos los que dijeren Bendita / sea la Purisima Inmaculada Concepcion de la Beatisima Virgen M Junio 4 de 1646 ARJ».

17. Ramón Mujica: «España eucarística y sus reinos: el Santísimo Sacramento como culto y tópico iconográfico de la monarquía», en JuAna Gutiérrez Haces (coord.): Pintura de los reinos. Identidades compartidas. Territorios del mundo hispánico siglo XVI-XVIII, vol. 4, Fomento Cultural Banamex, México, 2008, pp. 1098-1167.

18. Eusebio de Nieremberg: Devoción y Patrocinio de San Miguel, Príncipe de los Ángeles, Antiguo Tutelar de los Godos, y Protector de España, por María de Quiñones, Madrid, 1643, p. 161.

19. Sobre este asunto véase mi tesis de doctorado: DомÉnech, La imagen de la Mujer del Apocalipsis. 


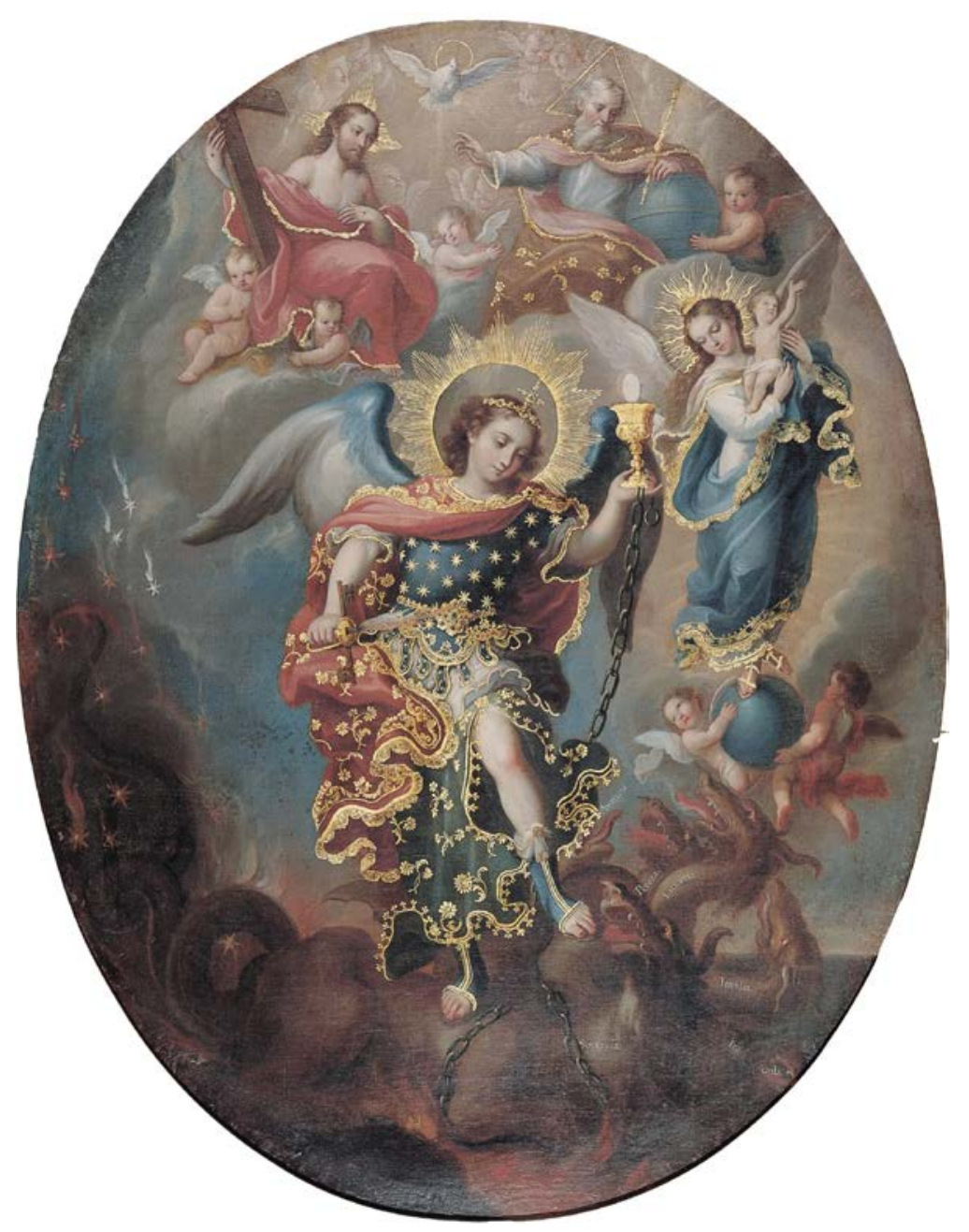

Fig. 4. Miguel Cabrera (atrib.), San Miguel vence a la bestia apocalíptica con ayuda de la eucaristía, s. XviıI, Museo de la Museo de la Basílica de Guadalupe, México

carácter en defensa de la fe. Por otro lado, la relación de la Mujer del Apocalipsis con la eucaristía se produjo en las representaciones narrativas medievales y renacentistas del capítulo 12 del Apocalipsis. En un grabado de Lucas Cranach el Viejo (s. XVI) se representa el añadido del arca de la alianza, la cual contenía un poco de maná, tipo veterotestamentario de la eucaristía. ${ }^{20}$ En el Beau tapis de Monsieur d'Anjou, obra de siglo $\mathrm{XIV}^{21}{ }^{21}$ se muestra el templo celeste con las puertas abiertas y, en el interior de este, un altar eucarístico. Por último, una

20. «Y el templo de Dios fue abierto en el cielo, y el arca de su pacto se veía en el templo» (Ap 11, 19).

21. Tapiz tejido en París entre 1373-1379 por Nicolas Bataille sobre cartones de Jean Bondol de Brujas para el duque Luis I de Anjou, Angers (Maine-et-Loire), castillo ducal, galería nueva. 
miniatura del Apocalipsis de la Reine Eleonor de Inglaterra (c. 1242-1250), conservado en el Cambridge Triniti College, un ángel entrega el «sustento eucarístico» a la mulier durante su espera en el desierto (Ap 12, 6). ${ }^{22}$

Esta relación entre la apocalíptica y el dogma eucarístico se fue imponiendo a medida que esta se convirtió en perfil iconográfico determinante de la Inmaculada. Esta concordancia presenta a María como corredentora y, con ello, vinculada al misterio eucarístico. Esto era una parte básica del fundamento concepcionista, el ver la Inmaculada Concepción de María como paso necesario e indispensable para la redención del género humano. Esta actitud visual estuvo en consonancia con lo expresado desde los púlpitos. En la sede catedralicia de Oaxaca, con motivo de la celebración de la coronación de Carlos II, el dominico fray Pedro del Castillo pronunció, en el año de 1677, un sermón convertido en laudatio al monarca y a su madre, Mariana de Austria, identificada como digna encargada de la transmisión de poderes. ${ }^{23} \mathrm{El}$ autor dedicó el sermón a la Inmaculada, uniéndola con el dogma eucarístico, y reconociendo el desempeño de la casa de Austria en este asunto. ${ }^{24}$ No fue el único caso sino que, en otras tantas ocasiones, los oradores novohispano ahondaron en las relaciones tejidas entre ambos asuntos. Uno de estos ejemplos es el del mercedario Juan de Castro en un sermón desplegado con motivo de la primera misa de un nuevo sacerdote. El predicador nos informa que fue el propio sacerdote, de la Orden de san Francisco, el que quiso dedicar su primera celebración eucarística a la Inmaculada uniendo ambos misterios por «entender que querer aplausos del primer instante puro con júbilo del sacrificio de su Misa». ${ }^{25}$ En conclusión, estas imágenes de San Miguel, además de continuar con la tradición visual de este arcángel como archiestratega, servían para presentarlo como uno de los adalides del rey del cielo y significar el carácter militante de la Iglesia ante la necesidad de defender los principios dogmáticos, siendo además todo ello reflejo de la política hispánica del periodo.

22. DomÉnECH: «Iconografía de la Mujer del Apocalipsis», pp. 563-580.

23. Pedro del CAstillo: Sermón de la Inmaculada Concepción de la Santissma Virgen Maria Reyna de los Angeles y Señora Nuestra. Descubierto el Santísimo Sacramento del Altar y en ocasión, que la Nobilissima Ciudad de Oaxaca, dio principio à las fiestas Reales de la Coronación, y nuevo gobierno de N. Rey y Señor Carlos Segundo (que Dios Guarde) [...], Francisco Rodriguez Lupercio, México 1677.

24. Según la tradición, la fama y esplendor de la familia de los Austrias estuvo profetizada por un sacerdote tras un acto de piedad eucarística protagonizado por su fundador, Rodolfo I. La leyenda relata que este, habiendo salido de caza acompañado por su escudero Regulus van Kyberg, se encontró con un sacerdote que, con intención de portar el viático a un moribundo, trataba de cruzar el río. Rodolfo I salió en su ayuda y le cedió su caballo. El sacerdote, conmovido por aquel acto de amor eucarístico, profetizó la grandeza de la dinastía de los Habsburgo. Esta costumbre fue continuada por el resto de sus descendientes, incluyendo Carlos II, en encuentros que debieron tener algo de planificado y que son muestra de un ritual cortesano de legitimación monárquica. Véase, Víctor Mínguez Cornelles: Los reyes solares. Iconografía astral de la monarquía hispánica, Universitat Jaume I, Castellón, 298-304; Víctor Mínguez Cornelles: La invención de Carlos II. Apoteósis simbólica de la casa de Austria, Centro de Estudios Europa Hispánica, Madrid, 2013.

25. JUAN DE CASTRO: Sermon panegirico en alabanza de la obra de la Concepcion a cuyo Puro instante consagrò su primera Missa el P. Predicador Fr. Martin de Zearreta, Religioso de el Orden de San Francisco, que cantò en el Convento de Santa Ines desta Ciudad el dia siete de Março deste año de 1690, Herederos de la Viuda de Bernardo Calderón, México, 1690, fr. 3v. 
La identificación de los seres angélicos a modo de milicias celestes fue también un recurso habitual en la devoción mariana. La idea de que la Virgen disponía de una guardia personal de ángeles, desde el momento exacto de su nacimiento, se encontraba presente en los siglos XVII y, sobre todo, en el XVIII, muy especialmente tras la publicación de la Mística ciudad de Dios, escrita por la concepcionista sor María de Agreda y publicada póstumamente en 1670. Así mismo, en la configuración de una jerarquía celeste, María ocupaba un lugar preeminente, tras la Trinidad y previo a los ángeles. El caso más significativo es el del arcángel Gabriel quien los evangelios identifican como el mensajero de Dios encargado de anunciar a María que había de concebir al Mesías. Aunque en el caso de Gabriel no se encuentre ninguna representación visual de su participación en acciones bélicas, lo cierto es que se puede apreciar, en la presentación que de él se realizaba en la literatura devocional, el carácter militar-aristocrático con el que era identificado. Todo ello en su doble papel de embajador de Dios y miembro de la corte de guardia de la Virgen. Un buen ejemplo lo tenemos en El embajador de buenas nuevas, san Gabriel arcángel, de Francisco García, publicado en 1683. Este jesuita recoge la tradición combatiente del arcángel Gabriel, proveniente de la literatura medieval, al decir que participó, junto a san Miguel, en la lucha contra los ángeles rebeldes. ${ }^{26}$ Aunque, sin duda, el lugar que ocupó dentro de la visión del cielo como una monarquía, es el del citado papel de embajador: «Particularmente los embajadores deben tomar este supremo embajador por patrón, para ejercer cargo tan importante y dificultoso con acierto y utilidad de su república». ${ }^{27}$

Pero, como decíamos, en la tradición visual Gabriel no muestra en su atuendo ningún elemento militar como la coraza de Miguel o el lábaro inmaculista, pero sí es representado vestido de gala. El carácter aristocrático de su tarea lo suele mostrar como un notable embajador, a pesar de que en el evangelio de Lucas no se describe el modo en el que estaba vestido: «... no pinta san Lucas el traje y aparato del Celestial Embajador, que sin duda fue de mucha gala, y lucimiento, como para tal embajada». ${ }^{28}$ Junto con su identificación como emisario de Dios, se encuentra la de capitán de la guardia personal de la Virgen María. Así se expresa nuevamente Francisco García:

Y como María por reina de los cielos y de la tierra debía tener muchos ángeles de la guarda, o mucha guardia de ángeles, debía ser el Capitán de esta guardia Gabriel; sino lo fue Miguel General de toda la milicia celestial, la cual sin duda sentó este la plaza en la Guardia de María, queriendo ser soldados de la Madre de Dios los que lo eran de su Hijo, gozando Gabriel de la honra de Capitán del

26. Francisco García: El embaxador de buenas nuevas, san Gabriel arcangel. Consagrado a la Reyna de los Angeles, y de los hombres María Madre de Dios, por Juan García Infançon, Madrid, 1683, p. 9.

27. GARCíA, El embaxador de buenas nuevas, p. 31.

28. Ibid., p. 14. 
Escuadrón, o ejército que asistía inmediatamente a María. Y debía ser Gabriel el custodio de María. ${ }^{29}$

Esta lectura tuvo nuevamente una versión guadalupana. Así, desde el púlpito de la basílica de Guadalupe, el 24 de abril de 1742, en el último sermón de la novena realizada a expensas de la Real Audiencia con motivo del conflicto bélico que las tropas españolas mantenían con Gran Bretaña, ${ }^{30}$ se pedía a la Virgen de Tepeyac que intercediese a favor de las tropas españolas. En presencia de los representantes de dicha autoridad de la Nueva España, el sacerdote José Fernández de Palos manifestaba: «Veré si puedo aun entre el ruido de las Armas examinarlos [los asuntos del sermón], que, aunque al hacer la reseña el Ángel Gabriel, Capitán de sus Tropas [de la Virgen de Guadalupe], amenazan algunas turbaciones». ${ }^{31}$

En el culto angélico también estuvo muy presente la devoción a los Siete Príncipes o arcángeles de Palermo que, a pesar de tener su origen en Europa y una significativa tradición en el entorno de la monarquía hispánica, constituye un caso singular para los virreinatos americanos..$^{32}$ Lo cierto es que en los tratados que abordan la devoción a este septenario angélico fue un recurso habitual presentarlos por medio de una comparativa cortesana, en la que eran presentados como altos dignatarios de la divinidad. Uno de los primeros autores que, en territorio americano, trató el asunto de los Siete Príncipes fue Alonso Alberto de Velasco, cura de la iglesia del Sagrario de la catedral de México, en la Semana angélica. ${ }^{33}$ En su tratado devocional sobre estos seres los describe como ministros de Dios y propagadores de la fe. Por otra parte,

29. GARCíA, El embaxador de buenas nuevas, p. 16.

30. Se trataba de la conocida como guerra del Asiento, que mantenía enfrentado -principalmente en el Caribe- a España y Gran Bretaña. Parte del escenario de conflicto bélico tuvo lugar en el norte de México. No olvidemos que Florida -territorio de Nueva España- compartía frontera con la inglesa Georgia. El sermón trata de las victorias sucedidas hasta el momento a favor de las tropas españolas, entre ellas la defensa del puerto de Veracruz. Antes de la celebración de esta novena en el templo del Tepeyac, se había celebrado otra a la Virgen de los Remedios.

31. José Fernández de PAlos: Triumpho obsidional que implora, y se anuncia La Real Audiencia Gobernadora de este Reyno de la Nueva España, por medio de la Virgen María N. Señora en su portentosa Imagen de Guadalupe, imprenta Real del Superior Gobierno, y del Nuevo Rezado de Doña María de Rivera, México, 1743, p. 198v.

32. Existe un número considerable de trabajos que abordan el tema de los Siete Príncipes de los que destacamos algunos, como el libro de Ramón Mujica, primer estudio minucioso sobre el impacto de este culto en América: Ramón Mujica Pinilla: Ángeles apócrifos en la América virreinal, Fondo Económico de Cultura, Lima, 1996; EsCardiel GonzÁlez Estévez: «Los Siete Príncipes de los Ángeles, un culto para la Monarquía», en Víctor Mínguez CORNELles, Las artes y la arquitectura del poder, Universitat Jaume I, Castellón, 2013; Escardiel González Estévez: Los Siete Arcángeles. Historia e iconografía de un culto hererodoxo, (tesis de doctorado, Universidad de Sevilla, 201; SERGi Doménech García: «La formación de la imagen de los Siete Príncipes. Descripción diacrónica, fuentes y hermenéutica», Imago. Revista de Emblemática y Cultura Visual, 1 (2009), pp. 117-133; SERGi DoméneCH GARCíA: «Imagen y devoción de los Siete Príncipes angélicos en Nueva España y la construcción de su patrocinio sobre la "evangelización"», Ars Longa, 23 (2014), pp. 151-172.

33. Alonso Alberto de Velasco: Semana angélica y recuerdos a la devoción de los Siete Príncipes assistentes al Trono soberano de Dios, que lo consagra a la Santissima Reyna de los Angeles, María señora nuestra, por Francisco Rodríguez Lupercio, México, 1682. 
el jesuita Andrés Serrano recoge la tradición de identificarlos, como reza el título de una de sus dos obras dedicadas a los Siete Príncipes, como «validos del rey del Cielo». ${ }^{34}$ Pero lo cierto es que, a pesar de los relatos bélicos que trataban la participación angélica o las descripciones de sus prerrogativas, que escribieron autores como Alonso Alberto de Velasco, Rafael de Bonafé o Andrés Serrano, no existe representación como arcángeles militares en este grupo, más allá de san Miguel o Uriel con su espada flamígera, ${ }^{35}$ tratándose en el fondo de imágenes con carácter devocional y vinculadas, especialmente a partir del siglo XVIII, al culto en el entorno jesuita.

Otros textos devocionales de la época recogieron tanto el carácter bélico de los ángeles, como el papel primado de los tres canónicos -Miguel, Gabriel y Rafael-, presentándolos como auténticos aristócratas alados. Un caso notable es el de Rafael de Bonafé y su libro Títulos de Excelencia y oficios de piedad del arcángel san Rafael, escrito en Manila y publicado en Madrid, en 1659. Este sacerdote - perteneciente nuevamente a la Compañía de Jesús- escribe este relato tras salir de una grave enfermedad y como agradecimiento al arcángel a quien se había encomendado. ${ }^{36}$ El texto de Rafael de Bonafé, dedicado al arcángel Rafael, es en realidad un tratado sobre los Siete Príncipes que son presentados, en algunos pasajes, como ángeles beligerantes. Al arcángel Miguel lo presenta como el primado de los ejércitos celestiales, presidente de los coros angélicos, así como "príncipe de príncipes» «prepósito o prefecto del Paraíso» y que «el mismo arcángel dijo al gran Constantino que era el archiduque y Gran General del señor de los ejércitos». ${ }^{37}$ Bonafé nos ofrece una visión guerrera también de Rafael. ${ }^{38}$ Así, por ejemplo, dice que fue él quien en una sola noche "pasó a cuchillo a ciento ochenta y cinco mil del ejército de Sennaquerib, rey de Siria», tal y como se narra en el Libro de los Reyes. Bonafé prosigue diciendo que:

este ilustre trofeo de Rafael fue una sombra del que había de alcanzar Cristo, por medio de su preciosa sangre, del príncipe de las tinieblas, el cual, aunque vencido, y derribado de los celestiales alcázares por el invictísimo príncipe de los ángeles san Miguel; pero no preso, ni atado, sino suelto y libre [...]. Pues si este glorioso vencimiento de Cristo fue con tanta razón aclamado en el Cielo [...]. También merecerá aclamaciones el de Rafael, y el título gloriosos

34. Andrés Serrano: Los Siete Príncipes de los Ángeles, validos del Rey del Cielo, Bruselas, 1707.

35. La espada flamígera le corresponde por su identificación con el querubín dispuesto en la puerta del paraíso tras la expulsión de Eva y Adán. Por otra parte, Alonso Alberto de Velasco retoma la tradición de identificar al arcángel Uriel como el ángel que ayudó a las tropas cristianas de don Pelayo en la conquista del territorio peninsular que estaba en mano de los musulmanes.

36. DOMÉNECH, «Imagen y devoción de los Siete Príncipes», pp. 160-162.

37. RAFAEL DE BONAFÉ: Títulos de Excelencia y oficios de piedad del arcángel S. Rafael uno de los siete asistentes de Dios, presidente de la salud y protector de la casa y familia de Tobías [...], Francisco Nieto y Salcedo, Madrid, 1659, p. 3.

38. De Rafael dice también que es quien «nos enseña con que [siete] cadenas podemos tener atado al demonio Asmodeo, príncipe de la Lujuria». Bonafé: Títulos de Excelencia y oficios de piedad del arcángel S. Rafael, pp. 338-347. 
de Magno, pues su triunfo fue una sombra del que había de alcanzar Cristo de Lucifer, atándolo en el profundo del Abismo. ${ }^{39}$

Al amparo de esta interpretación que afecta al arcángel Rafael -que habitualmente era representado con el atributo del pescado que lo relaciona con la bíblica historia de Tobías-, encontraremos en el arte virreinal representaciones de Rafael con atavíos militares, como el san Rafael con alabarda que se representa en un lienzo quiteño de finales del siglo XVII [Fig. 5]. La alabarda, de origen medieval y utilizada hasta el siglo XVII, era un arma propia de los ejércitos de infantería, y gozó de éxito entre los cuerpos de élite de la nobleza. Fernando el Católico contó con una guardia privada de alabarderos, cuerpo que fue fundado durante su reinado, en 1504. Por tanto, la forma en la que es mostrado el arcángel Rafael identifica su condición como miembro de una élite militar.

Esta representación sirve para introducir una tipología particular del arte virreinal comúnmente conocida con el nombre de arcángeles arcabuceros, pertenecientes en realidad a un conjunto de representaciones que deben ser agrupadas bajo la categoría de arcángeles militares andinos. Se trata de series angélicas caracterizadas por la representación de estos seres angélicos como mandos militares o cuerpo de élite de guardia portando distintos instrumentos y armas militares como alabardas, lábaros, trompetas o tambores, sobresaliendo los representados que portan -en distintas posiciones- un arcabuz. Esta imagen se identifica como un tema propio del área andina, originándose a finales del siglo XVII en el Virreinato del Perú, teniendo como foco principal de producción Cuzco y sus alrededores, en una zona comprendida entre el lago Titicaca y La Paz. ${ }^{40}$ Una observación atenta de sus vestimentas permite distinguir entre dos modalidades: por una parte, los que van ataviados con trajes militares del último tercio del siglo xvin y, de la otra, los de traje de corte francés, muestra de la moda impuesta tras la llegada de los Borbones. ${ }^{41} \mathrm{Se}$ trata de un tipo de retrato angélico que pretende mostrarlos como altos representantes de las milicias, ${ }^{42}$ como se puede deducir por el hecho de que vayan vestidos a la manera de los aristócratas españoles. Su formación es muestra del proceso de mestizaje producido en el área andina y puede verse como una trasposición de ciertos personajes -ángeles guerreros- que participaban de la fiesta barroca virreinal. Por la vestimenta y por las armas que portan como atributos se trata de una tipología de ángeles guardianes, a imitación de los cuerpos de guardia privada de la realeza y el papado. Esta tradición se había

39. BonafÉ, Títulos de Excelencia y oficios de piedad del arcángel S. Rafael, pp. 42-43.

40. J. P. Herzberg: «Angels with guns. Image and interpretation», en Gloria in excelsis. The Virgin and Angels in Viceregal Painting of Peru and Bolivia, Center of Inter-American Relations, Nueva York, 1986, p. 64.

41. Con el virrey don Antonio José de Mendoza, marqués de Villargarcía, se generalizó en Perú la moda afrancesada, lo que se trasladó a la representación de los ángeles arcabuceros. MujıCA, Ángeles apócrifos, p. 257.

42. Delata este hecho el que vayan vestidos como aristócratas y portando la faja de mando. MujICA, Ángeles apócrifos, p. 258. 
iniciado en el arte bizantino donde los ángeles solían representarse con ropas fastuosas acorde con el esplendor del ceremonial de la corte imperial, siendo el antecedente más claro la imagen de san Miguel archiestratega.

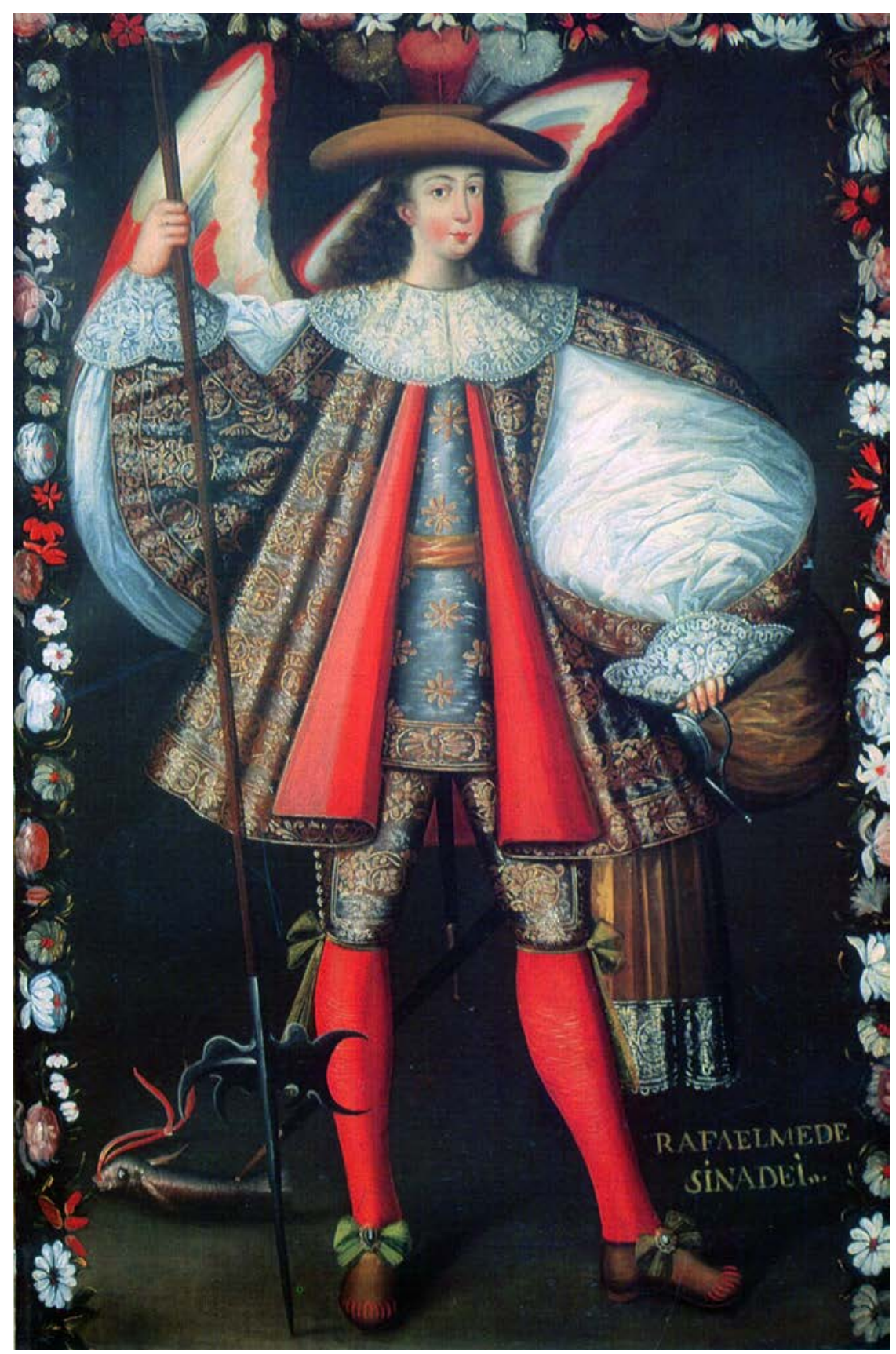

Fig. 5. Anónimo CUZQUEÑo, Arcángel Rafael con alabarda, finales s. XVII, colección particular 
Se trata de una imagen conceptual en la que, a pesar de estar vestidos con atuendo militar o de corte, estos seres angélicos no están ejecutando ninguna acción bélica. Suelen estar representados en un espacio neutro, intemporal, dominado por un fondo plano. Encontramos algunos casos-más bien excepciones- donde los ángeles se encuentran en medio de un paisaje. El origen del esquema compositivo de estas pinturas se encuentra en el manual de Jacob de Gheyn, El ejercicio de las Armas, publicado en 1607 en los Países Bajos [Fig. 6], de donde se toman las distintas posturas, o modos de llevar el arma, en las que son representados, como si se tratase de una demostración miliar. Esta obra disfrutó de gran difusión por toda Europa y América. Se trata de un manual ilustrado y con instrucciones sobre el uso de diversas armas, formado por 42 ilustraciones sobre el uso del arcabuz, 42 sobre mosquetes y 32 de picas. El repertorio de posturas del manual de Jacob de Gheyn incluye desde la forma en la que deben ser cargados los arcabuces, así como la posición de guardia que permite disponerse a punto para el disparo. En este sentido, las pinturas de los arcángeles arcabuceros se sirven de todos los modelos, tanto de los pasos intermedios, mostrando a los ángeles como en actitudes y posturas de exhibición, así como en las posiciones de carga o disparo, con la mecha prendida con la que se activa el arma. No obstante, algunas variaciones de estos tipos prescindieron de los detalles belicistas más activos. Una curiosa comparativa resulta de confrontar dos de idéntico esquema compositivo. Uno de ellos, conservado en el Museo de Nueva Orleans, muestra al arcángel -identificado con la inscripción Salamiel, pax dei- en posición de descanso, con el arcabuz apoyado en su hombro derecho mientras sujeta la mecha en la izquierda [Fig. 7]. Otro anónimo cuzqueño muestra la misma composición, con idéntico esquema compositivo, sustituyendo el fondo neutro atemporal del primero por un paisaje con pájaros y plantas, mientras que la mecha ha sido sustituida por un pañuelo [Fig. 8].

Por lo general, los retratos de ángeles militares forman un conjunto en el que aparecen identificados, por medio de inscripciones, tanto los tres ángeles canónicos como toda suerte de ángeles apócrifos, aunque carentes -por lo general- de sus atributos particulares. Estas series se completan con algunas variantes donde aparecen desprovisto del arcabuz y en su lugar ostentan como atributos otros útiles bélicos, incluyendo timbales y cornetas, y siguiendo el mismo tipo de vestiduras que se convierten en un atributo o perfil definitorio de esta imagen. Así, podemos encontrarnos también ángeles empuñando el sable, como el Hadriel del convento de la Concepción de Lima, en la serie de Calamarca, en la serie de Santa Bárbara, en Tunja u otros ejemplares en colecciones privadas [Fig. 9]. Por otra parte, en el Museo Pedro de Osma, de Lima, se conserva un lienzo de un ángel que porta escudo y vara de mando e identificado con la inscripción Timor dei [Fig. 10]. Estas series pueden incluir también ángeles tocando el tambor, de habitual uso miliciano, como en un anónimo cuzqueño donde el arcángel, identificado con la inscripción Eliel dei, es mostrado ejecutando un redoble sobre el citado instrumento de percusión. 


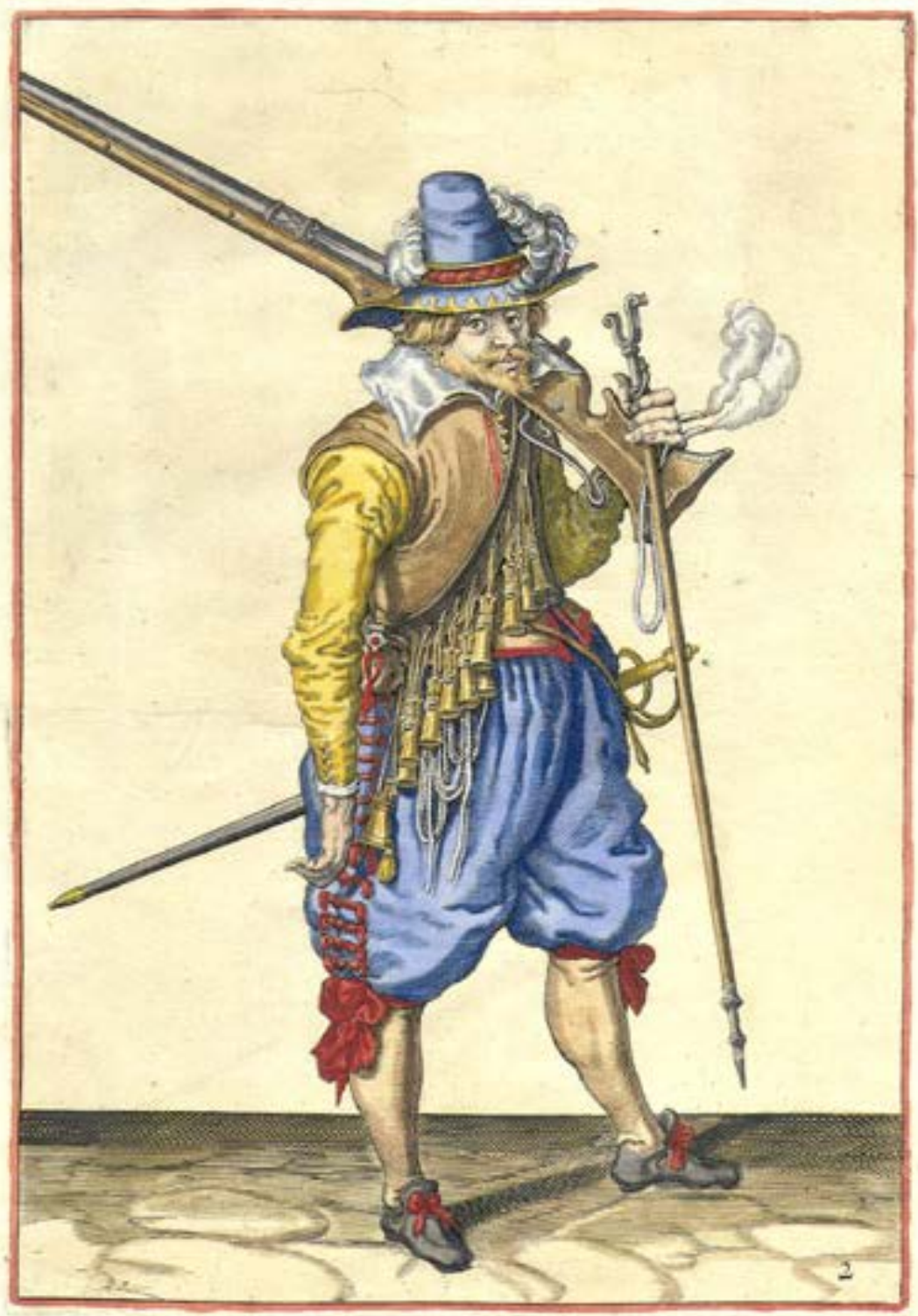

Fig. 6. Soldado con arcabuz, ЈАСов De GHeyn, El ejercicio de las Armas, c. 1607 


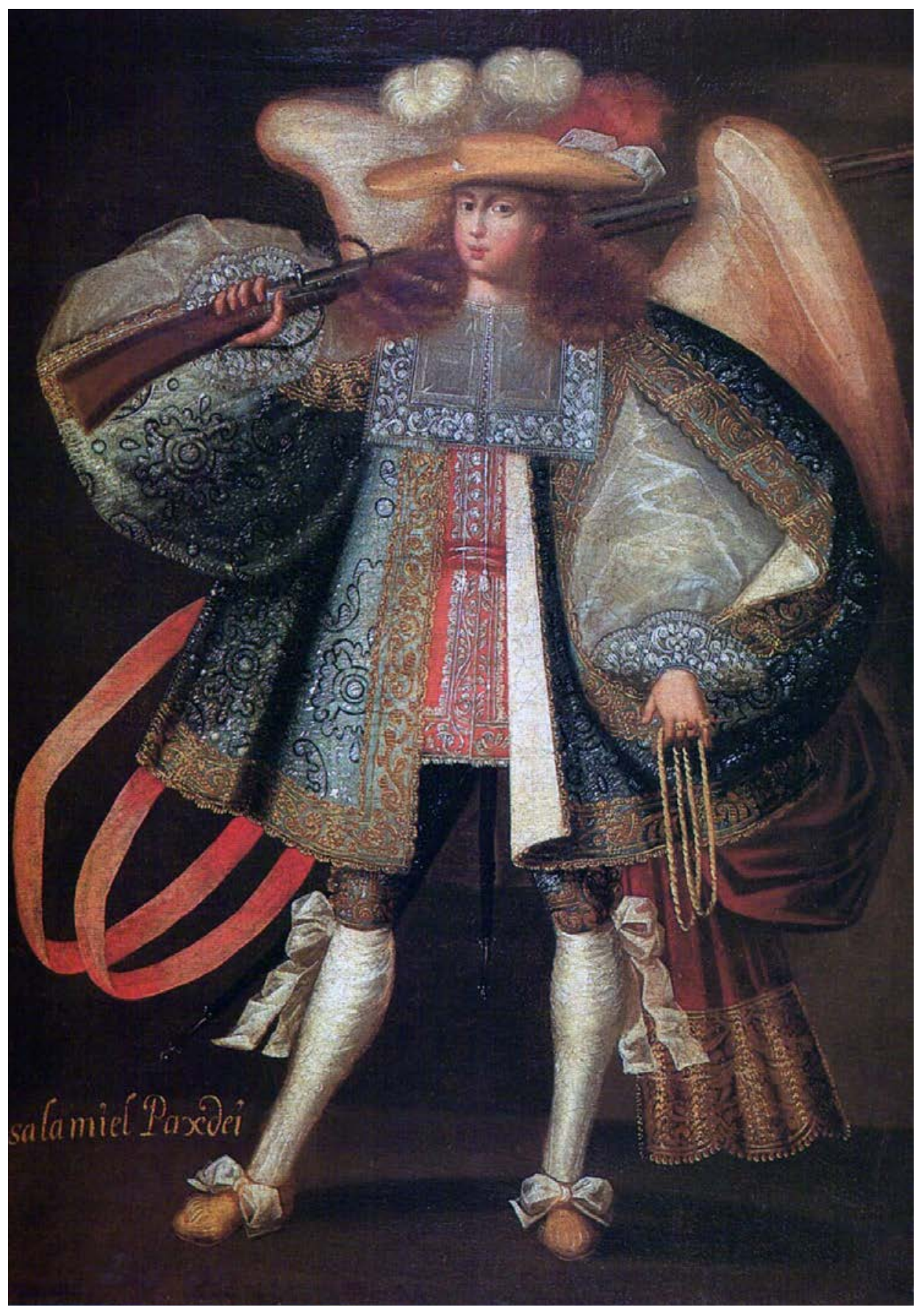

Fig. 7. Círculo del Maestro de Calamarca, Salamiel pax Dei, finales s. XviI, New Orleans Museum of Art 


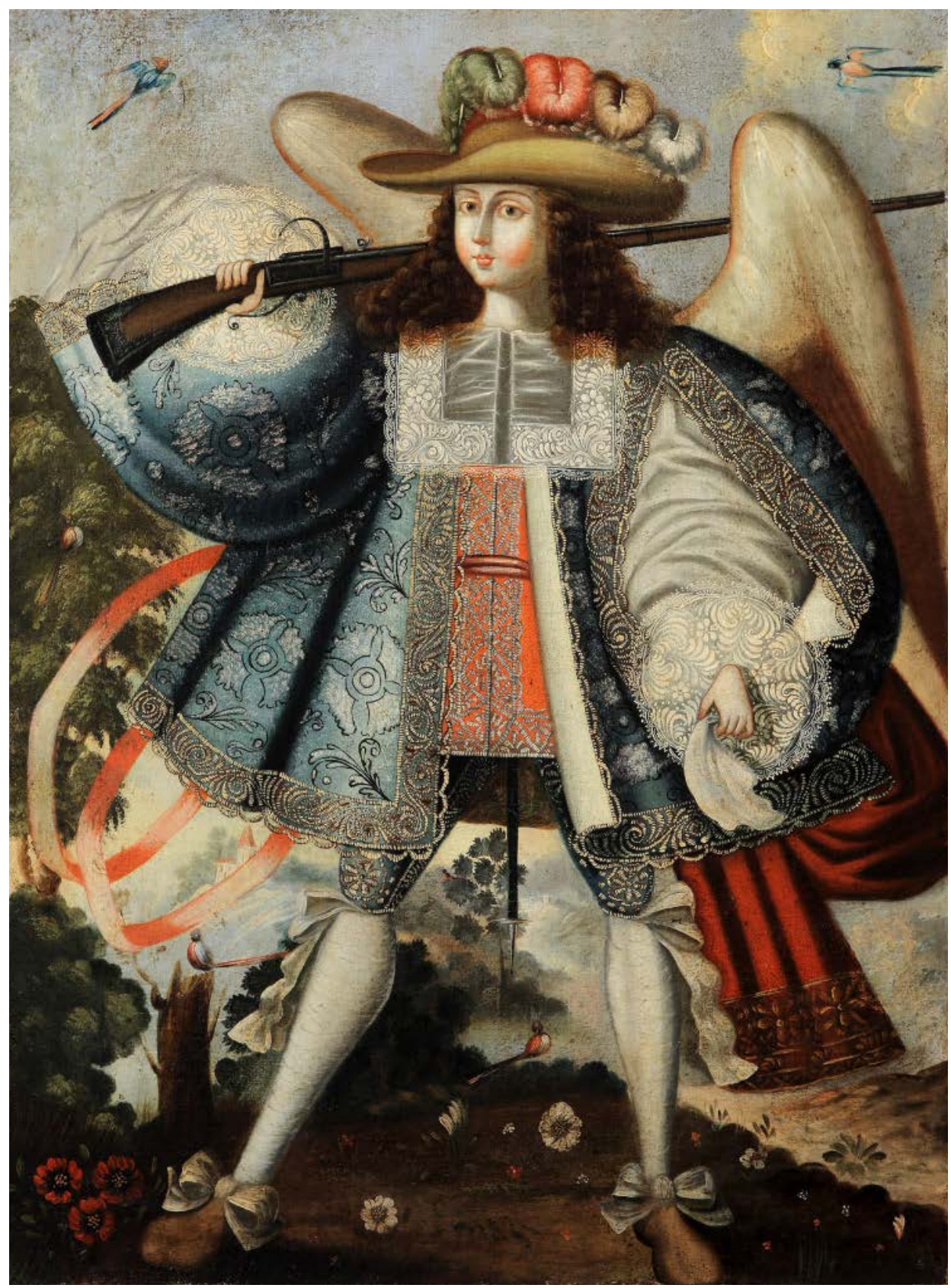

Fig. 8. ANónimo escuela CuZQueÑa, Arcángel arcabucero, s. XVII 


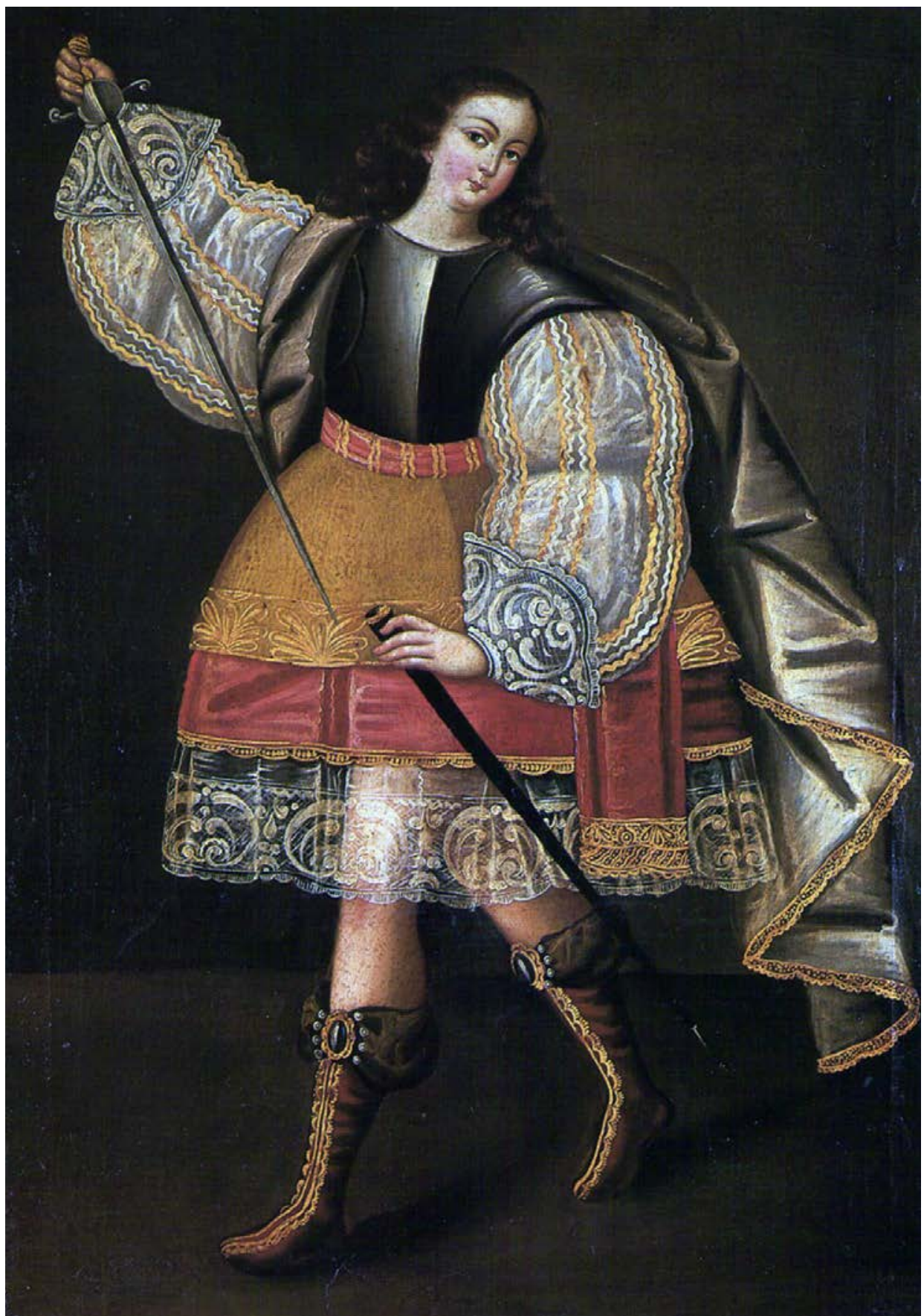

Fig. 9. Anónimo, Ángel enfundando la espada, s. XviI, Lima, Museo Pedro de Osma 


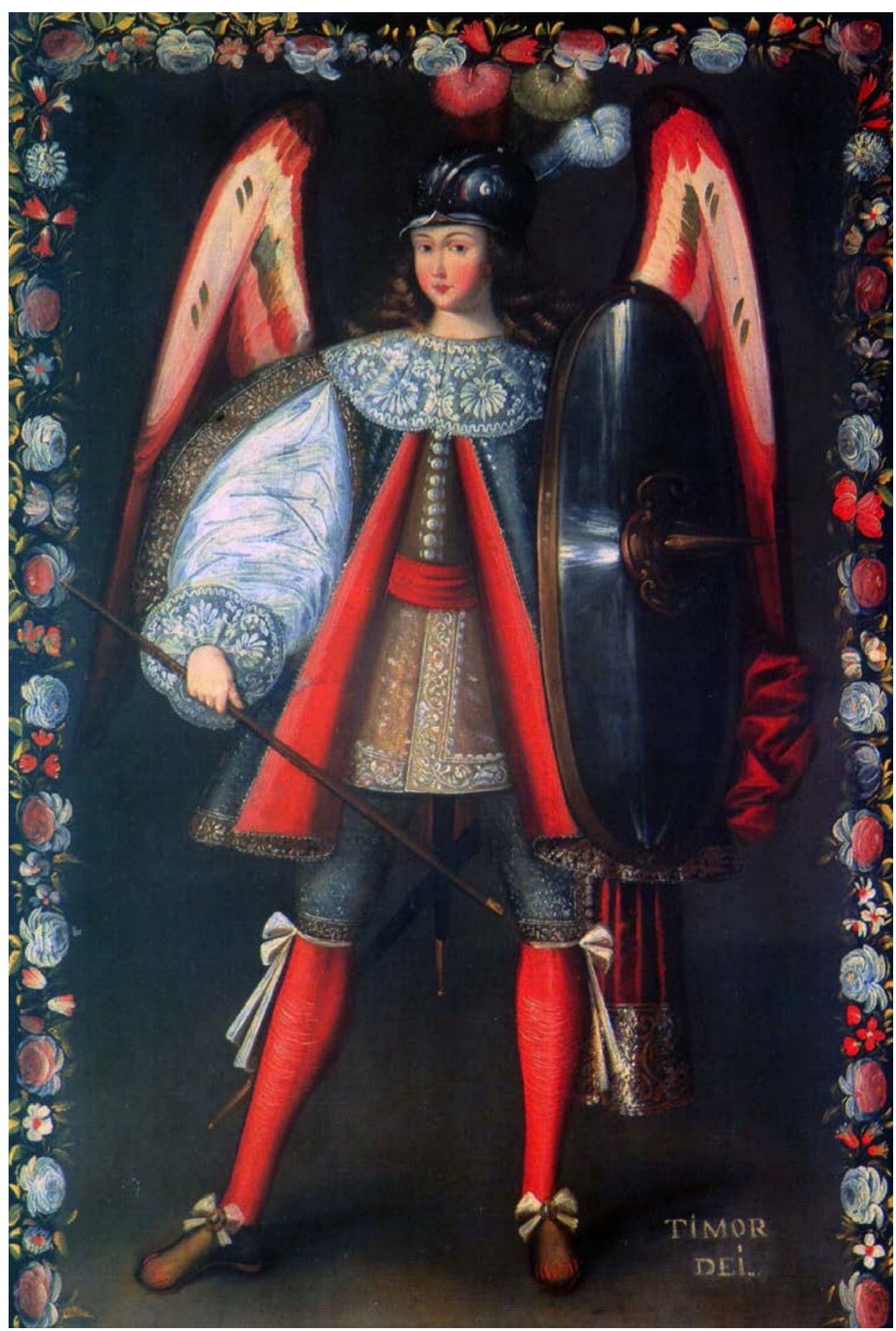

Fig. 10. Anónimo cuzqueño, Timor Dei, finales S. XviI, Lima, Museo Pedro de Osma 
Buen número de los ángeles militares-arcabuceros han terminado en colecciones particulares, aunque existen algunas series en sus lugares originales. Los primeros ejemplos de arcángeles arcabuceros conocidos en Bolivia se encuentran en Carabuco, pero la serie más importante es, sin duda, la de Calamarca, atribuida a José o Juan López de los Ríos. ${ }^{43}$ Esta serie está formada por diez ángeles militares. Unos portan el arcabuz en distintas posiciones [Fig. 11], mientras que otros son representados con alabarda, escudo, lanza, bandera o trompeta, siendo todos identificados por medio de inscripciones: Osiel Dei, porta casco y adarga; Zabriel Dei, portando la bandera; Michael, con una lanza; Rafael Dei, una partesana; Alami(el) Dei, con trompeta y corona; Hadriel Dei, carga el arcabuz al hombro; Leitiel Dei, presentando el arcabuz; Laeiel Dei, limpia el arcabuz con la baqueta; Uriel Dei, gatillando el arcabuz. ${ }^{44}$ Existen otras series angélicas donde algunos de ellos corresponden con la tipología de arcángeles militares, aunque ninguno de estos aparezca portando un arcabuz. Un ejemplo es la destacada serie de la iglesia de Sopó, en Colombia, formada por doce lienzos. ${ }^{45}$ En ella se representa un ángel con el apócrifo nombre de Piel que porta un estandarte militar y a otro, identificado como Esriel, que envaina su espada [Fig. 12].

En España se conserva una serie de origen andino en la ermita riojana de Nuestra Señora de Allende de Ezcaray formada por diez lienzos, aunque es muy probable que en origen fueran doce. En estos se muestran imágenes de arcángeles -entre ellos los tres canónicos- vertidos con coraza militar y portando, en ocho de los diez casos, arcabuces [Fig. 13]. Además de los arcabuceros, se muestra a un arcángel portando una bandera blanca con la cruz roja y muestra la mano en la empuñadura de su espada ceñida al cinto. Además, cada uno de los ángeles está identificado con un símbolo de la letanía lauretana ${ }^{46}$ Con toda probabilidad se debe a don Pedro Antonio de Barroeta, arzobispo de Lima entre 1748 y 1759, el envío a Ezcaray, su población natal, de esta serie como obsequio a la ermita de la Virgen de Allende, lo que justifica los símbolos marianos. ${ }^{47}$ Desde la publicación, en 1948, del estudio sobre estos lienzos por parte de Jose J. Baustista Urrutia, esta serie de arcángeles había sido tenida por la única de origen americano existente en territorio peninsular que mostraba a los arcángeles con cartelas marianas, aunque recientemente

43. Mario Ávila Vivar, Luis miguel Muñoz Fragua: «Los ángeles marianos de Tartanedo», Pátina, 13-14, época II (mayo, 2006), pp. 137.

44. Teresa Gisbert, José de Mesa: Los ángeles de Calamarca, Compañía Boliviana de Seguros, La Paz, 1983, p. 10.

45. La serie está atribuida a un anónimo maestro de Sopó, pintor que debió estar activo en la zona finales del siglo xvir. Pablo Gamboa Hinestrosa: La pintura apócrifa en el arte colonial. Los doce arcángeles de Sopó, Editorial Universidad Nacional, Bogotá, 1996, p. 134.

46. Gisbert, De Mesa: Los ángeles de Calamarca, p. 11; La medialuna, de Pulchra ut luna; el castillo que se identifica con la torre de David; la fuente de la sabiduría; la azucena o lirium inter spinas; el cipres, quasi cypressun in Sion; la estrella, strella matutina; la rosa de Jericó; el speculum sine mácula; y la palma. Carla Marañón Prior: «Iconografía Inmaculista en la serie de los Ángeles conservada en la ermita de Allende en Ezcaray», Revista Sains Soleil, 1 (2009), p. 28.

47. MujicA, Ángeles apócrifos, p. 249. 


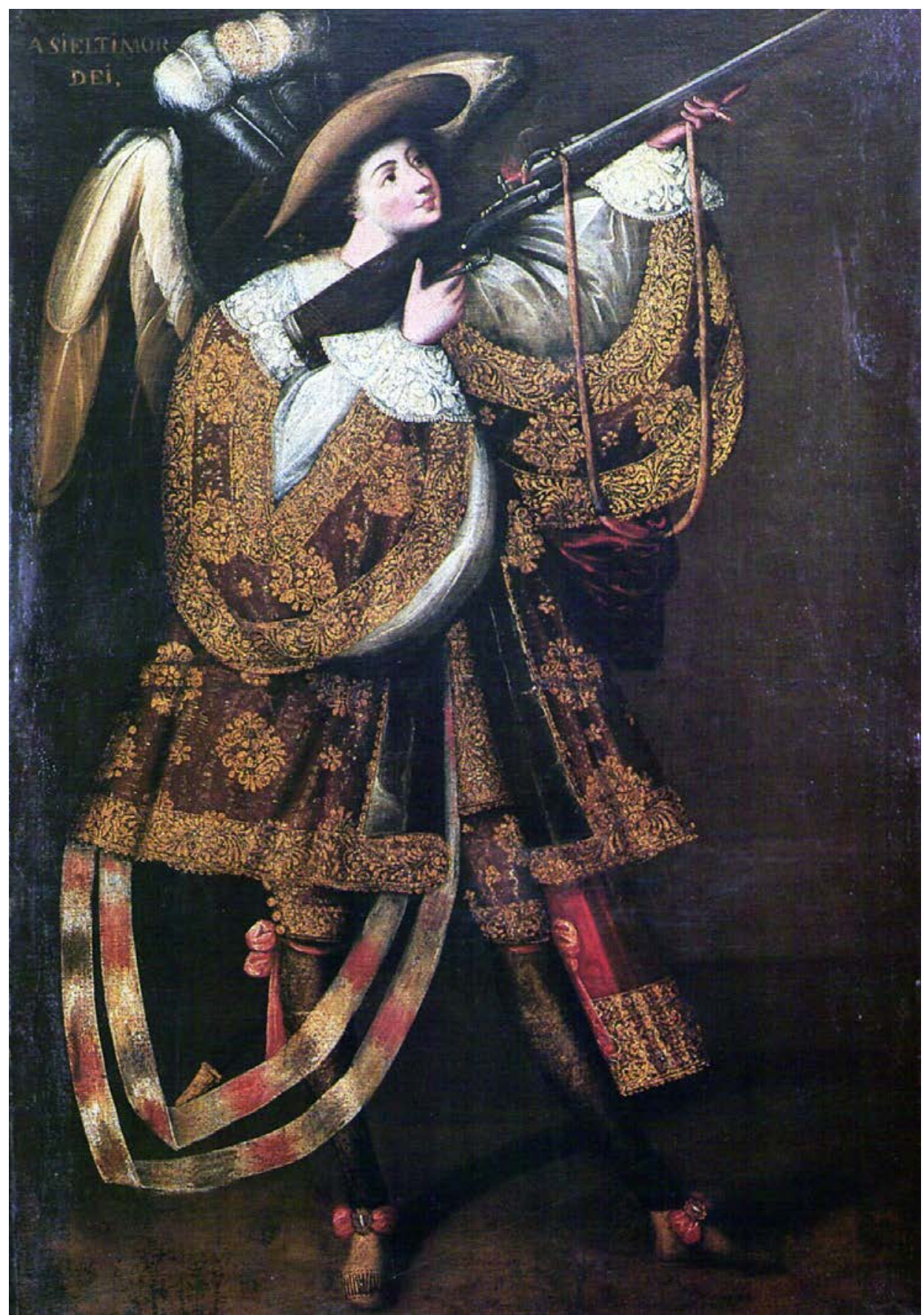

Fig. 11. Maestro de CalamarCa, Asiel Timor Dei, finales s. XVII, Museo Nacional de Arte, La Paz 


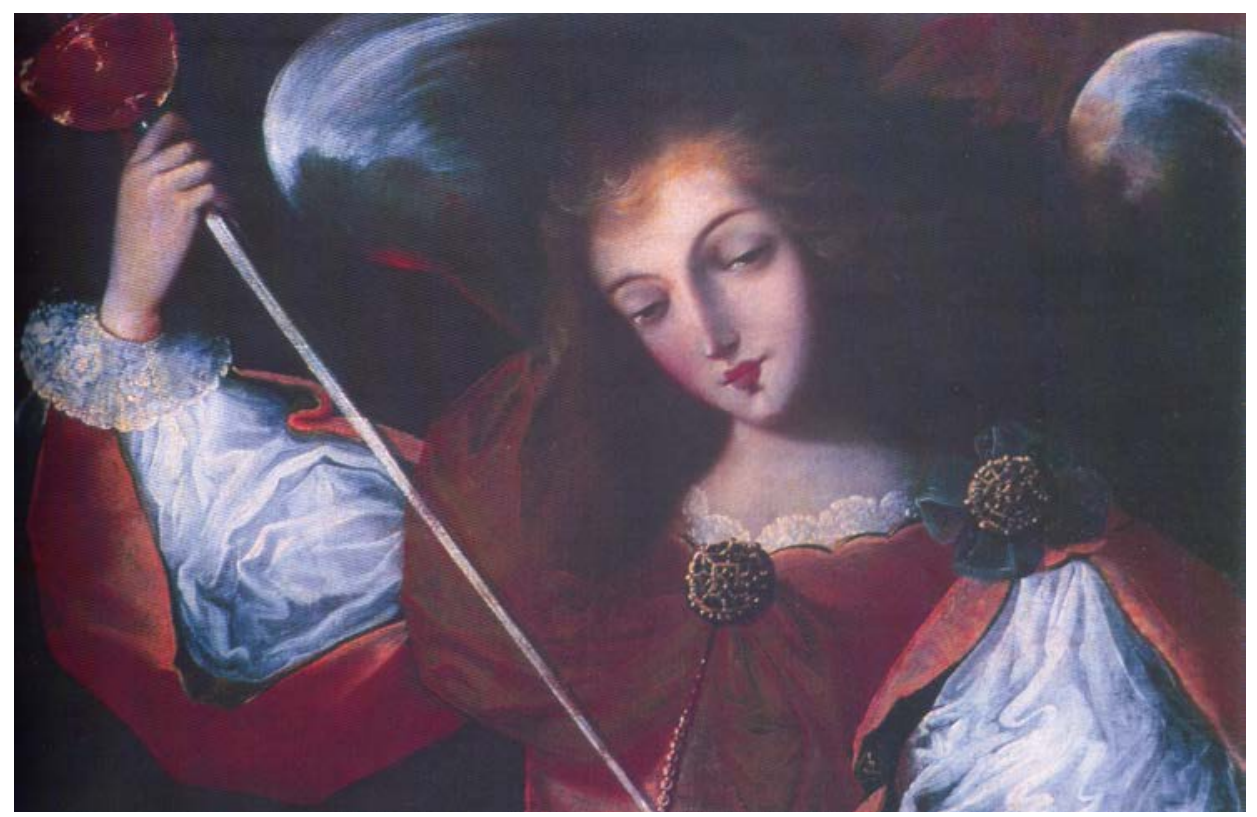

Fig. 12. Maestro de Sopó, Arcángel Esriel (detalle), finales del s. XVII, iglesia de Sopó

se atribuye el mismo origen a otra serie de arcángeles marianos -ninguno lleva arcabuz- perteneciente a la iglesia parroquial de San Bartolomé de Tartanedo. ${ }^{48}$

La función cultural que cumplían estas series angélicas ayuda a establecer una aproximación a la interpretación del arcángel arcabucero o militar andino. En virtud del contexto de las series, y en comparación con el imaginario visual de la época, resulta fácil comprobar que estas imágenes están definidas por su carácter apologético. Una buena muestra de ello se encuentra en la serie sobre la procesión del Corpus Christi de Cuzco, atribuidos a Basilio de Santa Cruz Pumacallao, que se conserva en el Museo de Arte Religioso de dicha ciudad. Estas pinturas han despertado un gran interés. El objetivo de las mismas fue trasladar «la imagen de república urbana unida y conciliada» y en ella se puede apreciar la participación de todas la comunidad, incluyendo participantes de las comarcas cercanas así como de los caciques cuzqueños, ataviados con las vestimentas de los señores incas. ${ }^{49}$

En uno de los lienzos, donde se aprecia el altar con la alegoría de Carlos II defendiendo la eucaristía, aparece un grupo de indígenas con uniforme

48. Ávila, MuÑoz, «Los ángeles marianos de Tartanedo», p. 137.

49. Víctor Mínguez, Inmaculada Rodríguez et alii: «El triunfo católico: la fiesta del Corpus Christi», La fiesta barroca. Los virreinatos americanos (1560-1808), Publicacions de la Universitat Jaume I / Universidad de Las Palmas de Gran Canaria, Castelló de la Plana, 2012, p. 136. 


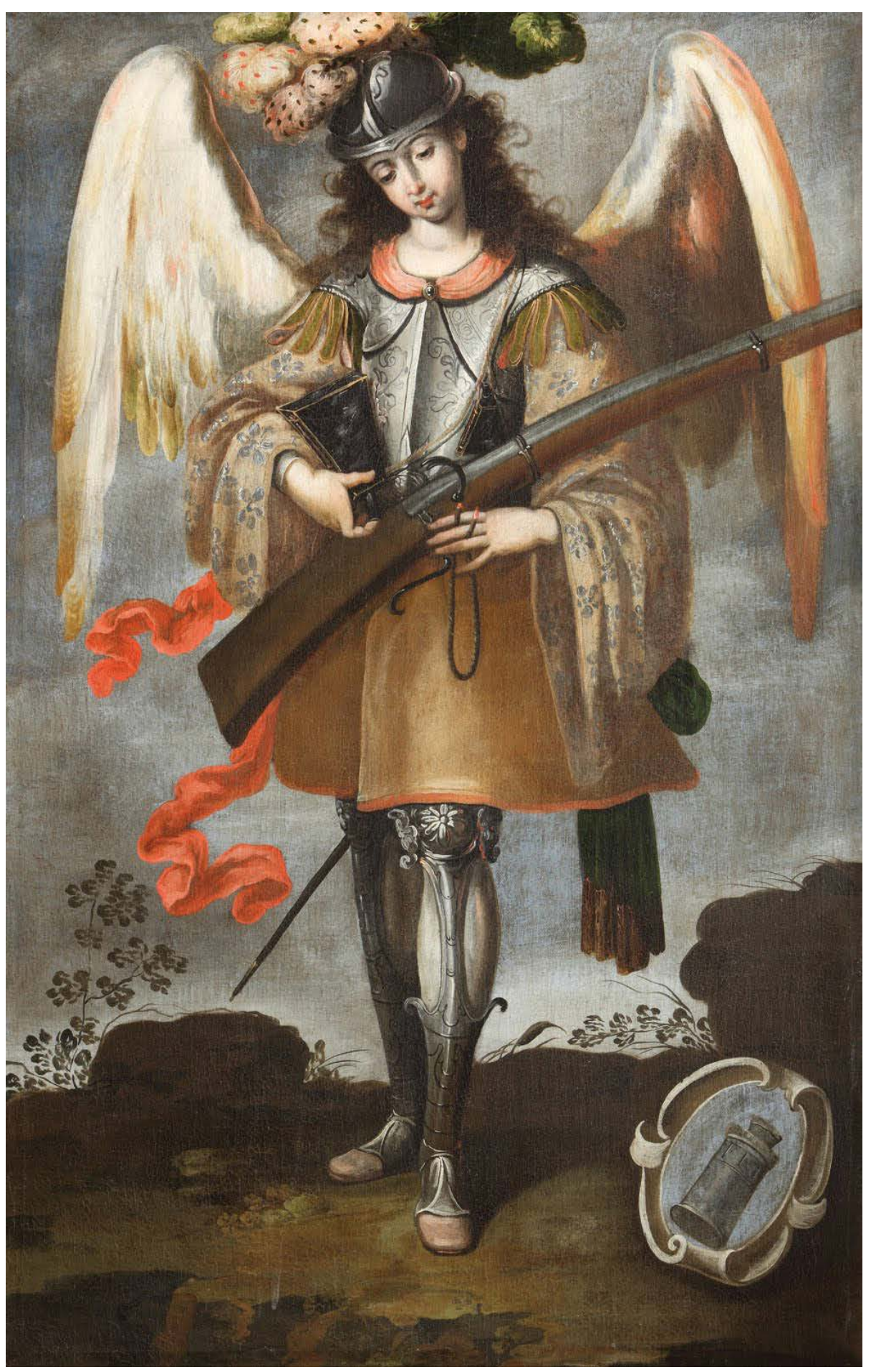

Fig. 13. Arcángel arcabucero con cartela mariana de la torre de David, s. XVIII, ermita de Nuestra Señora de Allende, Ezcaray (La Rioja) 


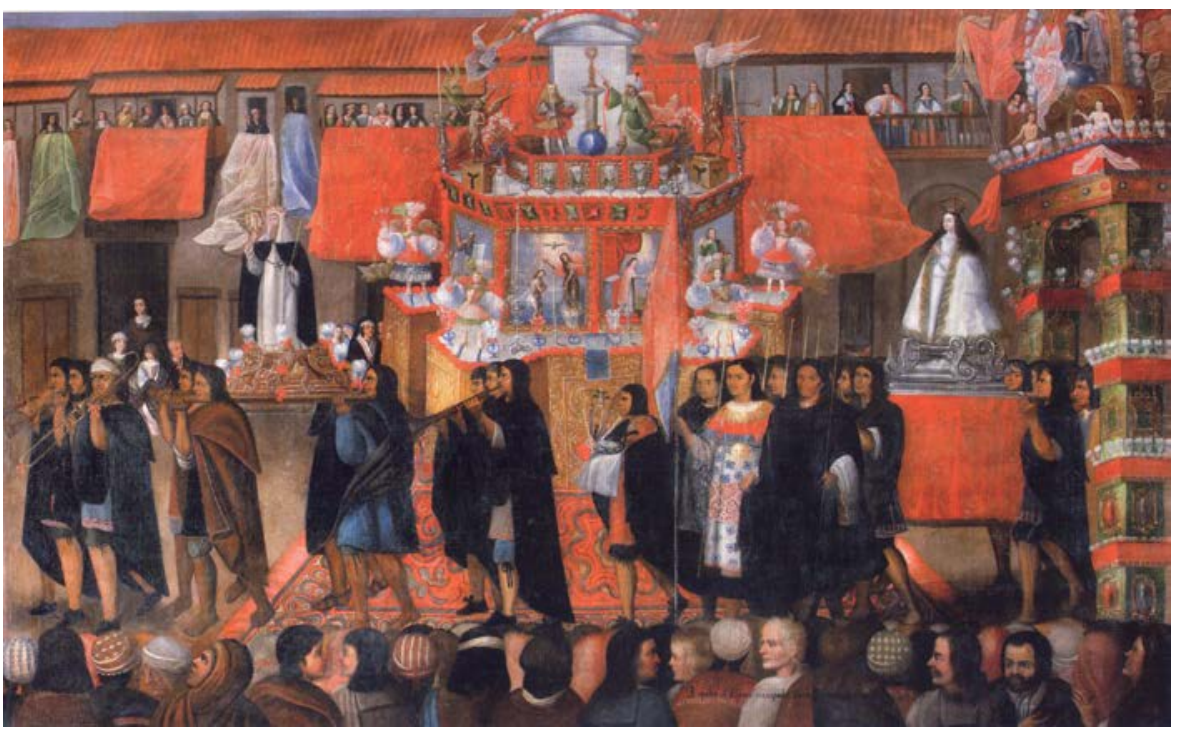

Fig. 14. Basilio de Santa Cruz Pumacallao (atrib.), Altar procesional de las confraternidades de Santa Rosa y «La Linda», serie del Corpus Christi, tercer cuarto del siglo XVII, Museo de Arte Religioso, Cuzco

aristócrata, vestidos con sombreros emplumado [Fig. 14]. ${ }^{50}$ En otro de los lienzos de la serie vuelven a aparecer ángeles -en este caso dos trompeteroscada uno sobre una mesa situada en el interior de unos nichos enmarcados con plumas blancas, a un lado y otro de un altar efímero que representa la Última Cena [Fig. 15]. Este altar se completa, en lo alto, con una galería de retratos de santas mártires -como santa Lucía y santa Bárbara- en lienzos que penden por debajo de la cornisa. Los arcángeles están presentes en un altar mariano formado por un graderío escalonado y, en cada nivel, la escultura de un representante angélico con un cirio en la mano y, en lo alto, una talla escultórica de la Virgen.

Probablemente vinculados con este uso festivo - como demuestra el lienzo del Corpus cuzqueño-, nos han llegado también esculturas policromadas de arcángeles arcabuceros, con el mismo esquema compositivo y atributos iconográficos que en los lienzos [Figs. 16 y 17]. Estas obras están realizadas en madera y yeso policromado por todos los frentes y cuenta con una amplia base cuadrada que les sirve de apoyo, lo que permitía su mejor adaptación a la decoración de altares efímeros. A la luz de estas obras y del lienzo de la festividad cuzqueña del Corpus Christi, lo que resulta muy probable es que, en origen, las series de lienzos de arcángeles militares y arcabuceros debieron utilizarse también en el empaliado de templos y conformación de altares incluso podría

50. Para un estudio de este lienzo, así como sobre la tradición visual de la defensa de la eucaristía en el mundo hispánico, véase MujICA, «España eucarística y sus reinos». 


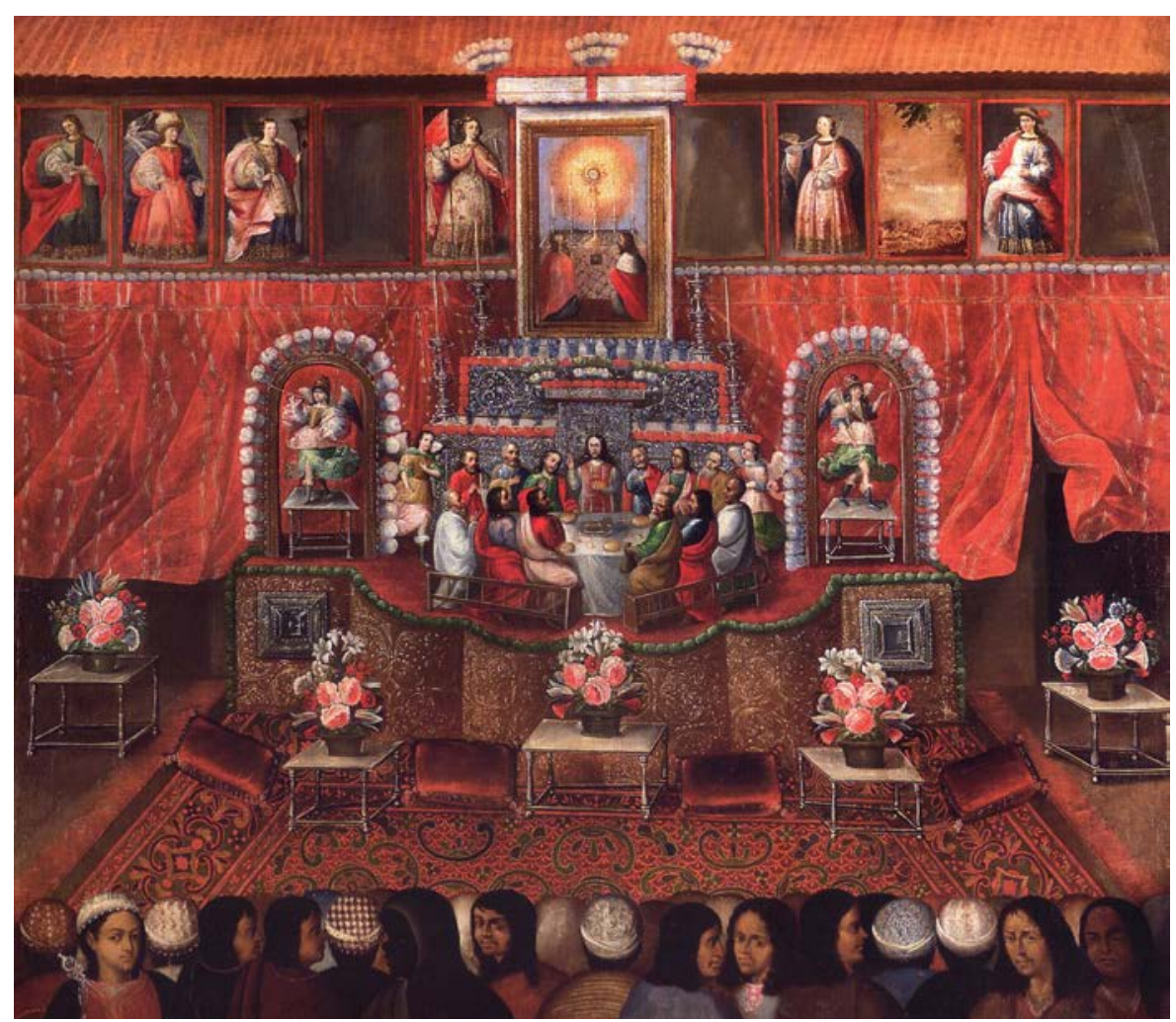

Fig. 15. Basilio de Santa Cruz Pumacallao (atrib.), Altar de la Última Cena, serie del Corpus Christi, tercer cuarto del siglo xviI, Museo de Arte Religioso, Cuzco

haber sido originalmente el motivo de su confección. Algunos de los ejemplos que nos han llegado presentan un habitual enmarcado a base de motivos florales. Lo cierto es que, de haber existido, no nos ha llegado ningún retablo-altar que presente un programa visual en el cual se integre la figura de estos arcángeles arcabuceros. De igual forma, las series conservadas en templos como la de Calamarca o Sopó, no ocupan un lugar especialmente adaptado dentro del templo sino que, como en Sopó, estos están dispuestos en la actualidad sobre el muro blanco. No obstante, cabe la posibilidad de que llegaran a formar parte de altares hechos retablo fingido en lienzo por medio de la técnica del trampantojo. Ese fue el destino que tuvieron, a su llegada a la iglesia de Tartanedo, ${ }^{51}$ los lienzos de los arcángeles marianos de origen americano. ${ }^{52}$

51. ÁviLA, MUÑoz, «Los ángeles marianos de Tartanedo», p.138.

52. A modo de comparación, sí nos encontramos en el caso de los Siete Príncipes composiciones y altares que, dedicados a estor seres angélicos, siguen un programa visual en el que son representados. De hecho, un ejemplo es altar fingido de la Santa Escuela de Cristo, en San Miguel Allende, donde aparecen los Siete Príncipes. En este artículo se reproduce uno de ellos, a san Miguel con el estandarte guadalupano. Véase DOMÉNECH, «Imagen y devoción de los Siete Príncipes», p. 160. 


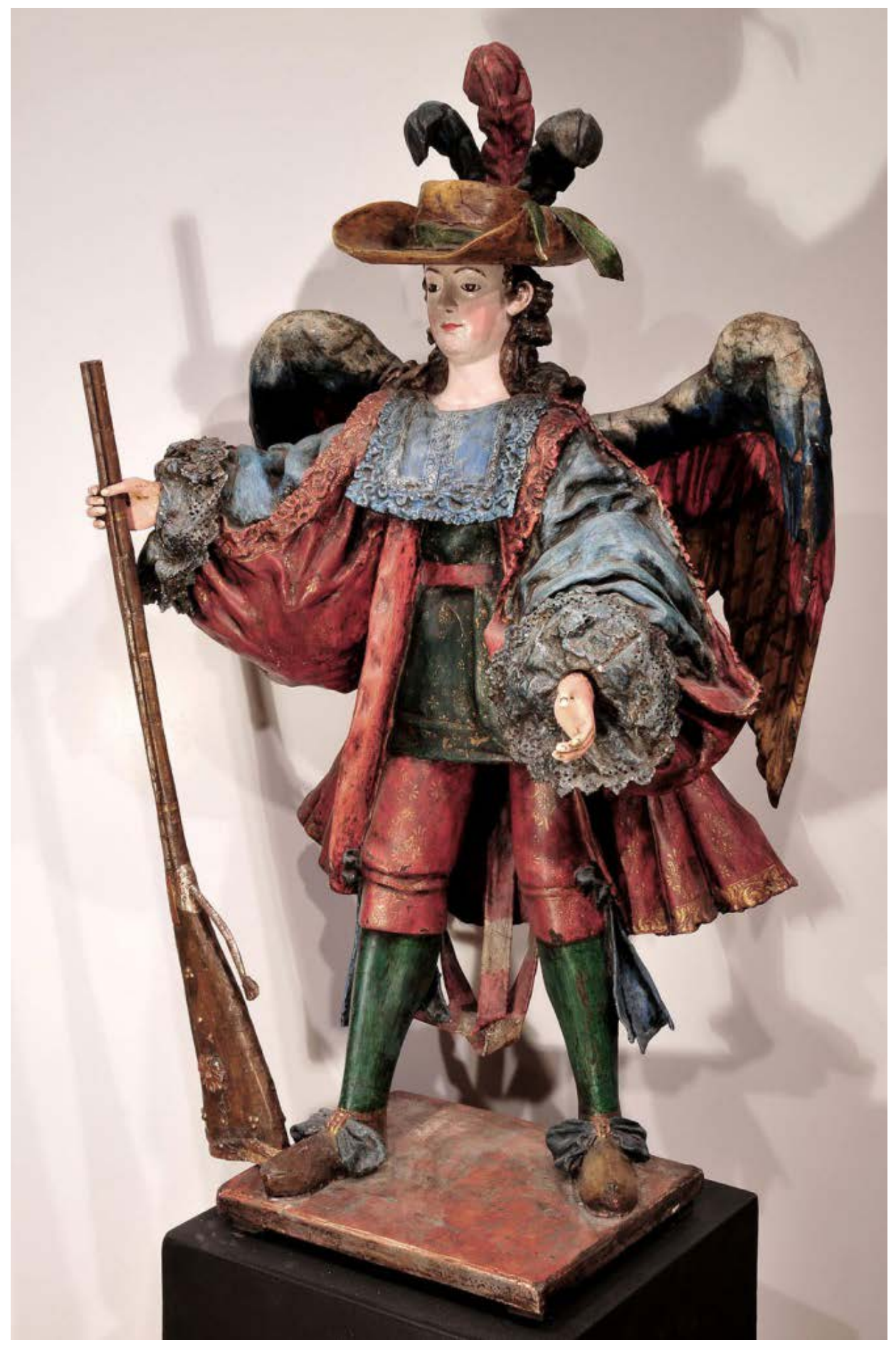

Fig. 16. Arcángel arcabucero, último tercio s. XviI, proveniente de Potosí (Bolívia), Peyton Wright Gallery 


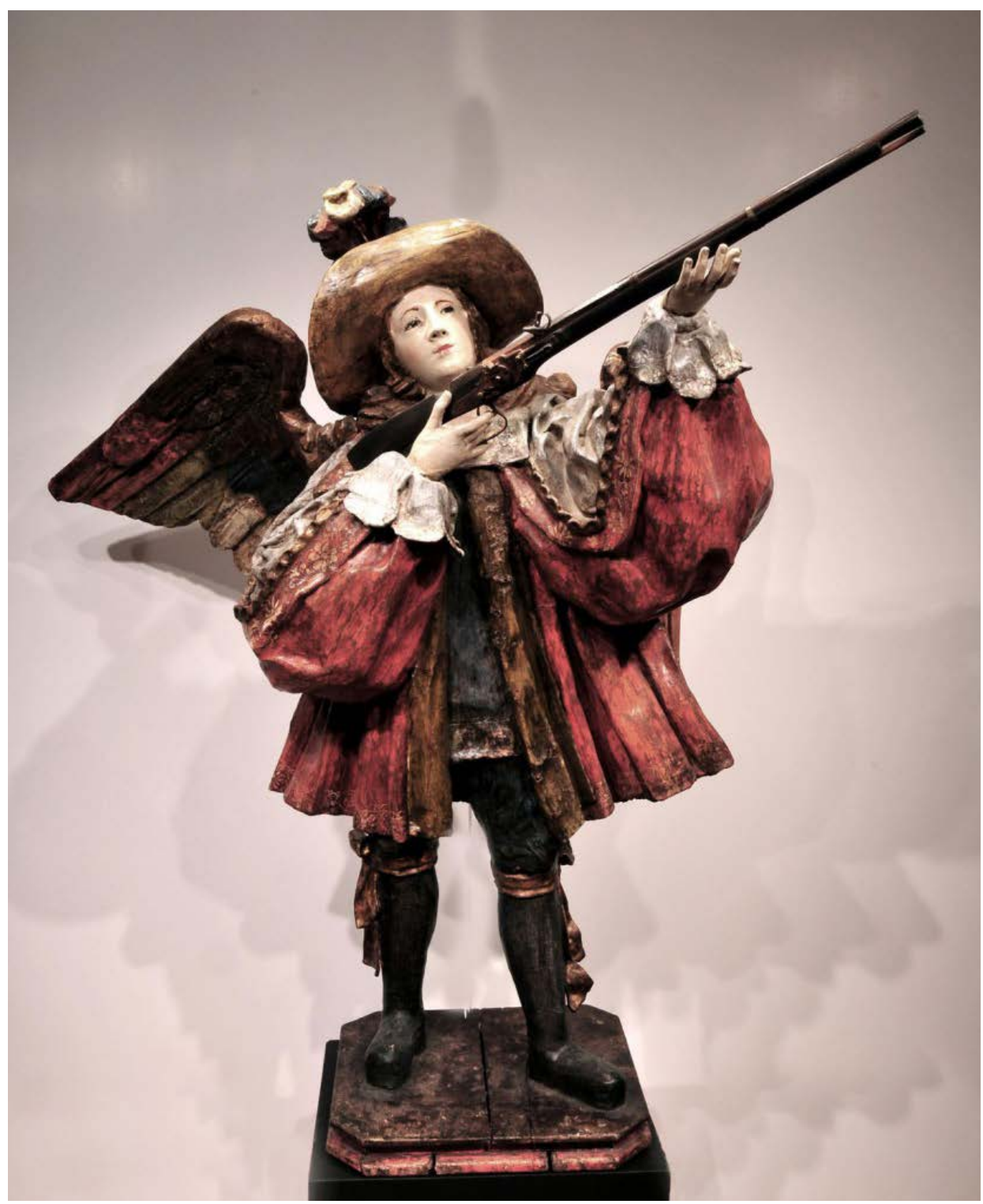

Fig. 17. Arcángel arcabucero, último tercio s. XVII, proveniente de Potosí (Bolívia), Peyton Wright Gallery

Estas imágenes demuestra la participación de las efigies de los arcángeles en una especie de liturgia pública o escenificación de una Iglesia militante y triunfante encomendada en la defensa de los principios de la fe católica, pero también del dogma eucarístico y como garantes del culto a la Virgen María. Los modelos cercanos a esta interpretación se encuentran en los carros alegóricos que, como en la serie de tapices de Rubens para las Descalzas Reales de Madrid, muestran a los herejes, musulmanes, protestantes e idólatras prehis- 
pánicos, pereciendo bajo las rotundas ruedas del carruaje de la Iglesia o la eucaristía. Estas series mostraban igualmente a los arcángeles a modo de una guarda personal mariana, e incluso garantes en la defensa de su Inmaculada Concepción, como en Ezcaray, conectando, como señaló en su momento Ramón Mujica, ${ }^{53}$ con la literatura devocional de la época, como en la obra de sor María de Agreda. La serie de Ezcaray muestra, además de las letanías, al arcángel Miguel en su tipo iconográfico de príncipe de las milicias celestiales, con la bestia apocalíptica humillada a sus pies. Porta espada y escudo, en cuyo interior se representa a la Inmaculada Concepción.

No se conoce fuente, más allá de los grabados de Gheyn, que dé una respuesta al atributo del arcabuz. Probablemente su detentación estuvo relacionada con la conquista del Perú, donde los cronistas dejaron escrito que los incas confundieron a los primeros conquistadores con viracochas, o mensajeros celestes de sus antiguos dioses que llegaban con arcabuces o truenos de mano. Ramón Mujica incluso llega a preguntarse si las representaciones de los arcángeles arcabuceros realizados en las últimas décadas del periodo habsbúrgico exponían formalmente a estos ángeles ataviados con el uniforme militar de gala con la intención de representar a los primeros conquistadores que confundieron a los indios, de mostrarlos como el ejército angélico encargado de defender la eucaristía y la Inmaculada Concepción o si, en un giro de carácter mesiánico, trataba de representar que «el imperio hispano con sus guerreros alados era el reino temporal escatológico de Cristo mencionado en el Apocalipsis». ${ }^{44}$

En conclusión, en el contexto de los virreinatos americanos han sido muchas las implicaciones culturales de este tipo de imágenes. En algunos casos su cultivo demuestra una deuda intencionalmente declarada con la tradición hispánica, mientras que en otros casos resulta evidente el encuentro con el aún presente pasado prehispánico. Este tipo de representaciones, en algún caso exclusivas del área andina, conectan con la tradición militar y aristocrática de la época, al representar a los ángeles tal y como si fuesen parte de un cuerpo militar, vestidos con trajes de campaña, y como miembros de la élite gobernante, evidenciando principalmente su condición de milicianos de Dios. Tras la conquista y dominación del territorio, hacia finales del siglo XVI, se inicia un proceso de definición -en el imaginario colectivo- de los territorios hispánicos como un espacio de resistencia y, por ello, de límites y fronteras. Esta concepción aparecía como consecuencia de la fabricación, por parte de los instrumentos del poder absoluto de la monarquía, del ideario de un orbe católico regido por un monarca mesiánico tenido como garante del catolicismo en el mundo. ${ }^{55}$ En la literatura devocional, los espejos de príncipes y, en

53. MujicA, Ángeles apócrifos.

54. MujicA, «España eucarística y sus reinos», pp. 1148-1149.

55. Fernando R. de la Flor: «Planeta católico», en Ramón Mujica Pinilla (ed.): El barroco peruano, Banco de Crédito, Lima, pp. 1-25. 
general, en la producción literaria de la época, se asienta esta visión que guarda una relación consustancial con la retórica visual, muy especialmente en la emblemática festiva en todas sus variedades. La activación de este imaginario se produce con la finalización de los procesos de conquista, cuando las fronteras se convierten en lugares amenazados territorialmente e ideológicamente. ${ }^{56}$ Además, en lo referente a la retórica visual de los virreinatos americanos, esta se manifestó como un artefacto potente, donde incluso la tarea misional seguía siendo una actividad presente. ${ }^{57}$ Tanto los ejemplos vistos de san Miguel con estandarte inmaculista, defendiendo la eucaristía, o los arcángeles militares y arcabuceros, participaron de la conformación de este imaginario colectivo.

56. Fernando R. DE LA Flor señala este principio como la base de la configuración del imaginario de la fortificación y su uso en la literatura y la emblemática del barroco hispánico. La fortaleza cumplía la función de proteger al Estado del enemigo, identificado como tal desde los luteranos, a africanos o a los propios indígenas, mismo que aparecían aplastados por los carros triunfales. FERNANDO R. DE LA FLOR: «El imaginario de la fortificación entre el barroco y la ilustración española», en AliCiA CÁMARA (coord.): Los ingenieros militares de la monarquía hispánica en los siglos XVII y XVIII, Ministerio de Defensa, Madrid, 2005, pp. 33-53.

57. Fernando R. DE LA Flor, «Planeta católico», p. 17. 